\title{
MASTER
}

\section{Solar-Climatic Statistical Study}

Summary Report

Volume 1 of 2

February 1979

Prepared for:

U.S. Department of Energy

Assistant Secrotary for Energy Technology

Office of Solar, Geothermal, Electric and Storage Systems

Under Contract No. EG-77-C-01-4016 


\section{DISCLAIMER}

This report was prepared as an account of work sponsored by an agency of the United States Government. Neither the United States Government nor any agency Thereof, nor any of their employees, makes any warranty, express or implied, or assumes any legal liability or responsibility for the accuracy, completeness, or usefulness of any information, apparatus, product, or process disclosed, or represents that its use would not infringe privately owned rights. Reference herein to any specific commercial product, process, or service by trade name, trademark, manufacturer, or otherwise does not necessarily constitute or imply its endorsement, recommendation, or favoring by the United States Government or any agency thereof. The views and opinions of authors expressed herein do not necessarily state or reflect those of the United States Government or any agency thereof. 


\section{DISCLAIMER}

Portions of this document may be illegible in electronic image products. Images are produced from the best available original document. 
Available from:

National Technical Information Service (NTIS)

U.S. Department of Commerce

5285 Port Royal Road

Springfield, Virginia 22161

Price: $\quad$ Printed copy: $\$ 5.25$

Microfiche: $\quad \$ 3.00$ 


\section{Solar-Climatic Statistical Study \\ Summary Report \\ Volume 1 of 2}

February 1979

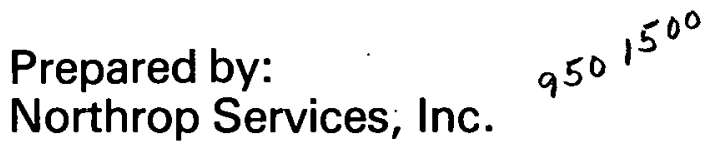

Huntsville, Alabama 35807

Prepared for:

U.S. Department of Energy

Assistant Secretary for Energy Technology

Office of Solar, Geothermal, Electric

and Storage Systems

Washington, D.C. 20545

Under Contract No. EG-77-C-01-4016

This report was prepared as an account of work Thinsored by the IInited States Govemment. Neither the Uniced States nor the United States Department of Energ, nor any of theis employees, nor any of their contractors subcon their employees, nor any of thet any warranty, erpmess of implied, or assumes any legal liability or responsibility for the accuracy, completentess is usefulness of any information, apparatus, product or prncess disclosed, or represents that its use would nu infringe privately owned rights. 


\section{NOTICE}

This report was prepared as an account of work sponsored by the United States Government. Neither the United States nor the United States Dejortinent of Enorgy, nor any nf their emnlnyees. makes any warranty, express or implied, or assumes any legal liability or responsibility for the accuracy, completeness, or usefulness of any information, apparatus, product, or process disclosed, or represents that its use would not infringe privately owned rights. Reference herein to any specific commercial product, process, or service by trade name, mark, manufacturer, or otherwise, does not necessarily constitute or imply its endorsement, recommendation, or favoring by the United States Government or any agency thereof. The views and opinions of authors expressed herein do not necessarily state or reflect those of the United States Government or any agency thereof. 


\section{FOREWORD}

This technical report presents work performed by Northrop Services, Inc., Huntsville, Alabama, while under contract (EG-77-C-01-4016) to the United States Department of Energy (DOE). The DOE Project Manager for the study was Mr. Michael R. Riches, Division of Planning and Technology Transfer (ETS), Environmental Planning and Analysis Branch. Technical coordination was provided by the Sandia Laboratories.

\section{ACKNOWLEDGMENT}

The author wishes to express his appreciation for the help and assistance provided by numerous individuals in the Northrop Services Engineering and Technology Center. Special recognition should be given to. Mr. James L. Hicks for his contributions in computational procedures and to Mr. Terry Asher for his assistance with data preparation. Particular acknowledgment is given to Mr. Marlin A. Sloan, Jr., Manager of Technology, for his helpful contributions and review comments.

Roger F. Bray

Principal Investigator 


\section{ABSTRACT}

Design and operation of large scale solar and wind energy conversion systems should be based, in part, on knowledge of expected solar and wind power trends. For this purpose, historic data at 26 (SOLMET) National Weather Service stations were processed to provide preliminary planning data, in the form of statistical information, for selected daily average solar and wind conditions occurring and persisting for time periods of interest. Solar data are global radiation incident on a horizontal surface, and wind data represent wind power normal to the air flow: Empirical probabilities were constructed from the historic solar and wind data to provide a reasonable inference of the chance of similar climatological conditions occurring at any given time in the future. (Diurnal wind power variations were also considered.) These data are presented in Volume II, and comprehensive plots for all stations are provided on a set of microfiche, contained in a folder in the back of Volume II.

Data used to obtaln the daily average solar and wind power probabilities were combined into monthly averages and are presented in this volume as summary results. Average monthly, seasonal and annual solar and wind power trends were prepared to provide an overview for identifying areas for further investigation. Documentation of the program (METPRO) developed to accomplish the overa11 study is included in the appendices of Volume II. 
TABLE OF CONTENTS - VOLUME I

Section

Title

Page

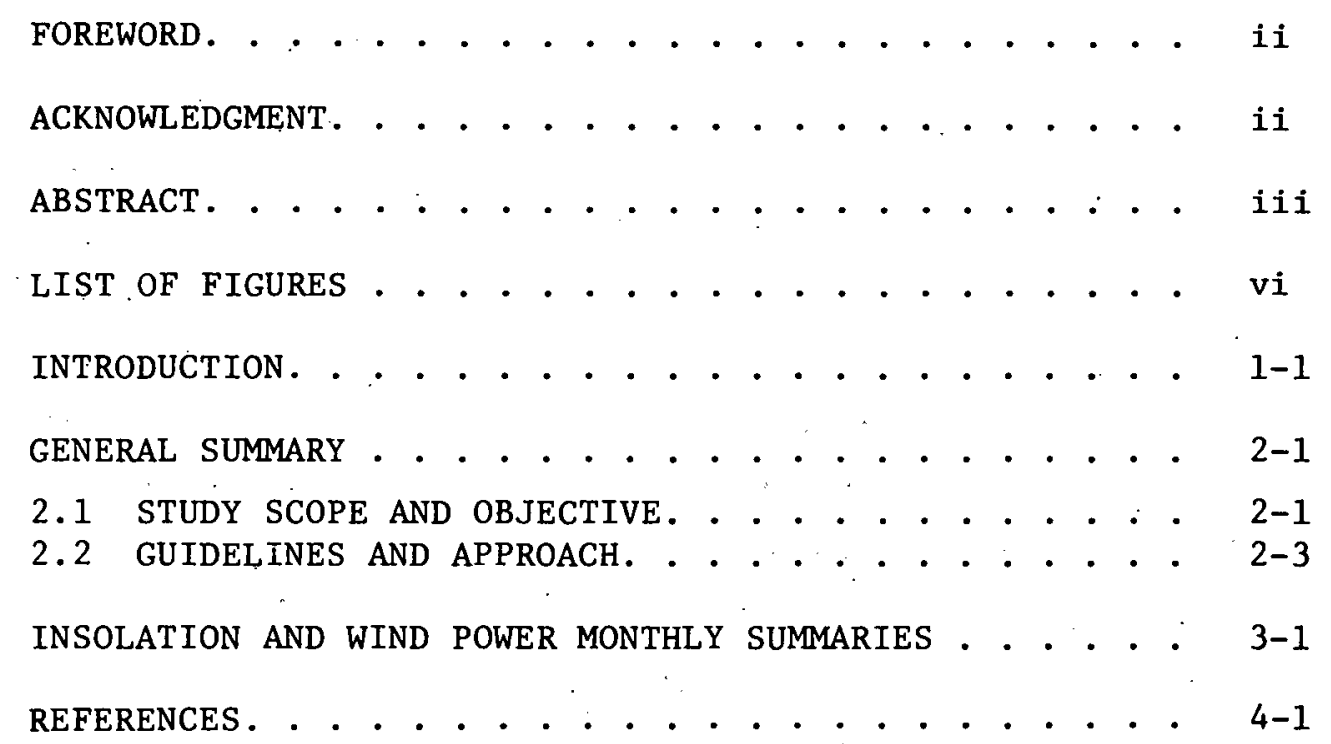




\section{TABLE OF CONTENTS - VOLUME II}

Section

Title

Page

FOREWORD. . . . . . . . . . . . ......

ACKNOWLEDGMENT . . . . . . . . . . . . . . . i i

ABSTRACT. . . . . . . . . . . . . . . . iii

LIST OF FIGURES . . . . . . . . . . . . . . . v

I

INTRODUCTION. . . . . . . . . . . . . . . . 1-1

II

TECHNICAL APPROACH. . . . . . . . . . . . . 2-1

2.1 METHODOLOGY. . . . . . . . . . . . . . 2-1

2.2 DATA REQUIREMENTS. . . . . . . . . . . $2-3$

2.3 3TATISTICAL TEChNIQ̨UES . . . . . . . . . 2-7

III

INSOLATION AND WIND POWER STATISTICS. . . . . . . 3-1

3.1 DISCUSSION OF FIGURES AND TABLES . . . . . . 3-3

3.2 SUCCESSIVE DAY PROBABILITIES . . . . . . . . . 3-8

3.3 PROBABILITIES OF PERSISTENCE . . . . . . . . . 3-8

3.4 JOINT PROBABILITIES. . . . . . . . . . . . . 3-8

3.5 SUMMARY. . . . . . . . . . . . . . . . . 3-9

REFERENCES. . . . . . . . . . . . . . 4-1

Appendix A - COMPREHENSIVE STATISTICAL RESULTS SAMPLE . . . . . . . . . . . . . A-1

Appendix B - TABLES - SUCCESSIVE DAY AND PERSISTENCE PROBABILITIES. . . . . . . . . . . . . B-1

Appendix C - SELECTED SOTAR AND WIND PLOTS. . . . . C-1

C.1 SUCCESSIVE DAY PROBABILITIES . . . . . . . . C-7

C. 2 PROBABILITIES OF PERSISTENCE . . . . . . . . . c-111

C. 3 JOINT PROBABILITIES. . . . . . . . . . . . C-163

Appendix D - PROGRAM METPRO . . . . . . . . . . D-1

D.1 GenERAL. . . . . . . . . . . . . . . . . . D-1

D. 2 METPRO1. . . . . . . . . . . . . . . . . $\mathrm{D}=2$

D.3 METPRO2. . . . . . . . . . . . . . . . D-7

Appendix E - PROGRAM LISTING. . . . . . . . . . . E-1

E.1 METPRÓ1 LISTING. . . . . . . . . . . . . E-3

E.2 METPRO2 LISTING. . . . . . . . . . . . . E-13 


\section{LIST OF FIGURES}

Figure

$\underline{\text { Title }}$

Page

2-1 SOLMET HOURLY REPORTING STATIONS. . . . . . . . . . . . 2-2

3-1 DAILY AVERAGE WIND POWER VS. DAILY AVERAGE WIND SPEED . . . • 3-2

3-2 AVAILABLE SOLAR AND WIND POWER - JANUARY . . . . . . . . 3-3

3-3 AVAILABLE SOLAR AND WIND POWER - FEBRUARY . . . . . . . . . 3-4

3-4 AVAILABLE SOLAR AND WIND POWER - MARCH. . . . . . . . . . 3-5

3-5 AVATLABLE SOLAR AND WIND POWER - APRIL. . . . . . . . . . 3-6

3-6 AVAILABLE SOLAR AND WIND POWER - MAY. . . . . . . . . . . 3-7

3-7 AVAILABLE SOLAR AND WIND POWER - JUNE . . . . . . . . . 3-8

3-8 AVATLABLE SOLAR AND WIND POWER - JULY . . . . . . . . . 3-9

3-9 AVAILABLE SOLAR AND WIND POWER - AUGUST . . . . . . . . . 3-10

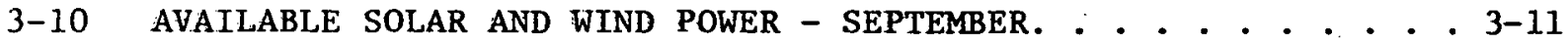

3-11 AVAILABLE SOLAR AND WIND POWER - OCTOBER. . . . . . . . . . . 3-12

3-12 AVAILABLE SOLAR AND WIND POWER - NOVEMBER . . . . . . . . . . 3-13

3-13 AVAILABLE SOLAR AND WIND POWER - DECEMBER . . . . . . . . 3-14

3-14 DAILY AVERAGE INSOLATION AND WIND POWER, BY MONTH AND ANNUAL AIBUQUERQUE, NM . . . . . . . . . . . . . . . 3-16

3-15 DAILY AVERAGE INSOLATION AND WIND POWER, BY MONTH AND ANNUAL APALACHICOLA, FL. . . . . . . . . . . . . . . . . 3-17

3-16 DAILI AVERAGE INSULA'IION AND WIND POWER, BY MONTH AND ANNUAL BISMARCK, ND. . . . . . . . . . . . . . . . . . 3-18

3-17 DAILY AVERAGE INSOLATION AND WIND POWER, BY MONTH AND ANNUAL BOSTON, MA . . . . . . . . . . . . . . . . . . . 3-19

3-18 DAILY AVERAGE INSOLATION AND WIND POWER, BY MONTH AND ANNUAL BROWNSVILLE, TX . . . . . . . . . . . . . . . . . 3-20

3-19 DATLY AVERAGE INSOLATION AND WIND POWER, BY MONTH AND ANNUAL CAPE HATTERAS, NC . . . . . . . . . . . . . . . . 3-21

3-20 DAILY AVERAGE INSOLATION AND WIND POWER, BY MONTH AND ANNUAL CARIBOU, ME . . . . . . . . . . . . . . . . . . 3-22

3-21 DAILY AVERAGE INSOLATION AND WIND POWER, BY MONTH AND ANNUAL CHARLESTON, SC. . . . . . . . . . . . . . . . . . 3-23

3-22 DAILY AVERAGE INSOLATION AND WIND POWER, BY MONTH AND ANNUAL COLUMB IA, MO . . . . . . . . . . . . . . . . . . . . . 3-24 


\section{LIST OF FIGURES (ConcIuded)}

Figure

$\underline{\text { Title }}$

$\underline{\text { Page }}$

3-23 DAILY AVERAGE INSOLATION AND WIND POWER, BY MONTH AND ANNUAL DODGE CITY, KS. . . . . . . . . . . . . . . . . . 3-25

3-24 DAILY AVERAGE INSOLATION AND WIND POWER, BY MONTH AND ANNUAL EL PASO, TX . . . . . . . . . . . . . . . . . 3-26

3-25 DATLY AVERAGE INSOLATION AND WIND POWER; BY MONTH AND ANNUAL ELY, NV . . . . . . . . . . . . . . . . . . . . 3-27

3-26 DAILY AVERAGE INSOLATION AND WIND POWER, BY MONTH AND ANNUAL FORT WORTH, TX. . . . . . . . . . . . . . . . . . . 3-28

3-27 DAILY AVERAGE INSOLATION AND WIND POWER, BY MONTH AND ANNUAL FRESNO, CA. . . . . . . . . . . . . . . . . . . . 3-29

3-28 DAILY AVERAGE INSOLATION AND WIND POWER, BY MONTH AND ANNUAL GREAT FALLS, MT . . . . . . . . . . . . . . . . 3-30

3-29 DAILY AVERAGE INSOLATION AND WIND POWER, BY MONTH AND ANNUAL LAKE CHARLES, T.A. . . . . . . . . . . . . . . . . . 3-31

3-30 DAILY AVERAGE INSOLATION AND WIND POWER, BY MONTH AND ANNUAL MADISON, WI . . . . . . . . . . . . . . . . 3-32

3-31 DAILY AVERAGE INSOLATION AND WIND POWER, BY MONTH AND ANNUAL MEDFORD, OR . . . . . . . . . . . . . . . . 3-33

3-32 DAILY AVERAGE INSOLATION AND WIND POWER, BY MONTH AND ANNUAL MIAMI, FL . . . . . . . . . . . . . . . . . 3-34

3-33 DAILY AVERAGE INSOLATION AND WIND POWER, BY MONTH AND ANNUAL NASHVILlE, TN . . . . . . . . . . . . . . . . 3-35

3-34 DATLY AVERAGE INSOLATION AND WIND POWER, BY MONTH AND ANNUAL NEW YORK, NY . . . . . . . . . . . . . . . . 3-36

3-35 DAILY AVERAGE INSOLATION AND WIND POWER, BY MONTH AND ANNUAL NORTH OMAHA, NB..................... 3-37

3-36 DAILY AVERAGE INSOLATION AND WIND POWER, BY MONTH AND ANNUAL PHOENIX, $\mathrm{AZ}$. . . . . . . . . . . . . . . . . 3-38

3-37 DAILY AVERAGE INSOLATION AND WIND POWER, BY MONTH AND ANNUAL SANTA MARIA, CA .................... 3-39

3-38 DAILY AVERAGE INSOLATION AND WIND POWER, BY MONTH AND ANNUAL SEATTLE-TACOMA, WA . . . . . . . . . . . . . . . . . 3-40

3-39 DAILY AVFRAGE INSOLATION AND WIND POWER, BY MONTH AND ANNUAL WASHINGTON, DC-STERLING, VA . . . . . . . . . . . . . . . 3-41. 


\section{INTRODUCTION}

National assessments are being made to find suitable test and evaluation locations for large scale solar and wind energy conversion systems. Design and operation of such systems, as well as site selection, should be based on knowledge of expected solar insolation and wind power trends at the locations. Thus; Northrop Services, Inc., performed a study to provide preliminary planning data, in the form of statistical information, for selected solar and wind conditions occurring and persisting for periods of time at selected sites. The sites are 26 (GOLMET) National Weather Service stations (ref. 10) measuring hourly insolation and collateral meteorological data. The data base for this study is the historical data that go back nearly 24 years for each station. The data are available from the National climatic Center.

Solar and wind energy available at the specific locations are compared by expressing these forms of energy in the same units of watts/square meter. Solar energy is the global radiation incident on a horizontal surface and wind energy is the wind power perpendicular to the air flow.

Empirical probabilities are constructed from the historical data to provide estimates of daily average insolation and wind power, independently and in combination, occurring and persisting at or above specified thresholds for up to one week. Diurnal wind power variations are also considered. (These data are presented in Volume II, along with the technical approach followed to accomplish the stidy.) Summary results have been prepared by combining into monthly averages the solar and wind values used in obtaining the above probabilities. Daily values were averaged over a month to obtain a monthly average value of insolation and wind power. These monthly averages were then averaged over the years of record to obtain average monthly values for insolation and wind power. Data were combined to show seasonal and annual trends, in addition to the monthly trends. 
Presented in Section II is a general summary of the study objectives and approach. Summary results assembled, as described above, for an overview of monthly, seasonal and yearly averages of insolation and wind power are presented in Section III. The program, METPRO, developed to accomplish the overall Solar-Climatic Statistical Study has been documented in Volume II. Program variable definitions, subroutine abstracts, flow charts and program listings provide the prospective user inclusive information for setting up and running program METPRO. 


\section{GENERAL SUMMARY}

The primary purpose of this study is to provide preliminary planning data to aid in assessing the feasibility of solar, wind, or hybrid solar-wind energy systems at or near 26 sites in the United States. Historic data at the 26 sites are available through the National Climatic Center (NCC) on magnetic tape for periods of up to 24 years. Hourly solar insolation and collateral meteurological data are recorded in a common tape format, SOLMET, and the 26 stations are referred to as the SOLMET stations. (Shown in Figure 2-1 are the relative locations of each station throughout the contiguous United States).

\section{Global solar radiation and wind speed data taken from the SOLMET tapes} are used to derive empirical probabilities for daily average insolation and wind power occurring and persisting, at or above specified levels, or thresholds, over time periods of interest. This study is based on previous work by Carter (ref. 3) and Graves (ref.6) in determining frequencies of occurrence of weather events. As in those studies, the term probability is also used here to mean the straightforward empirical probability obtained using the frequencies of occurrence of climatological variables at or above stated criteria.

\subsection{STUDY SCOPE AND OBJECTIVE}

The objective of the study was to provide probability estimates of insolation and wind power, alone and in combination, occurring and persisting at or above specified thresholds for up to one week. Basically, empirical probabilities were obtained for:

- average daily insolation and average daily wind power, independently, equaling or exceeding five thresholds, on a monthly basis, for successive occurrences of up to one week,

- persistence, for up to one week, of insolation and wind power, independently, at or above five thresholds, on a monthly basis, and

- the (successive) occurrence and persistence of joint combinations of insolation and wind puwer equaling or exceeding all permutations of three threpsholds each, also for periods of up to one week. 


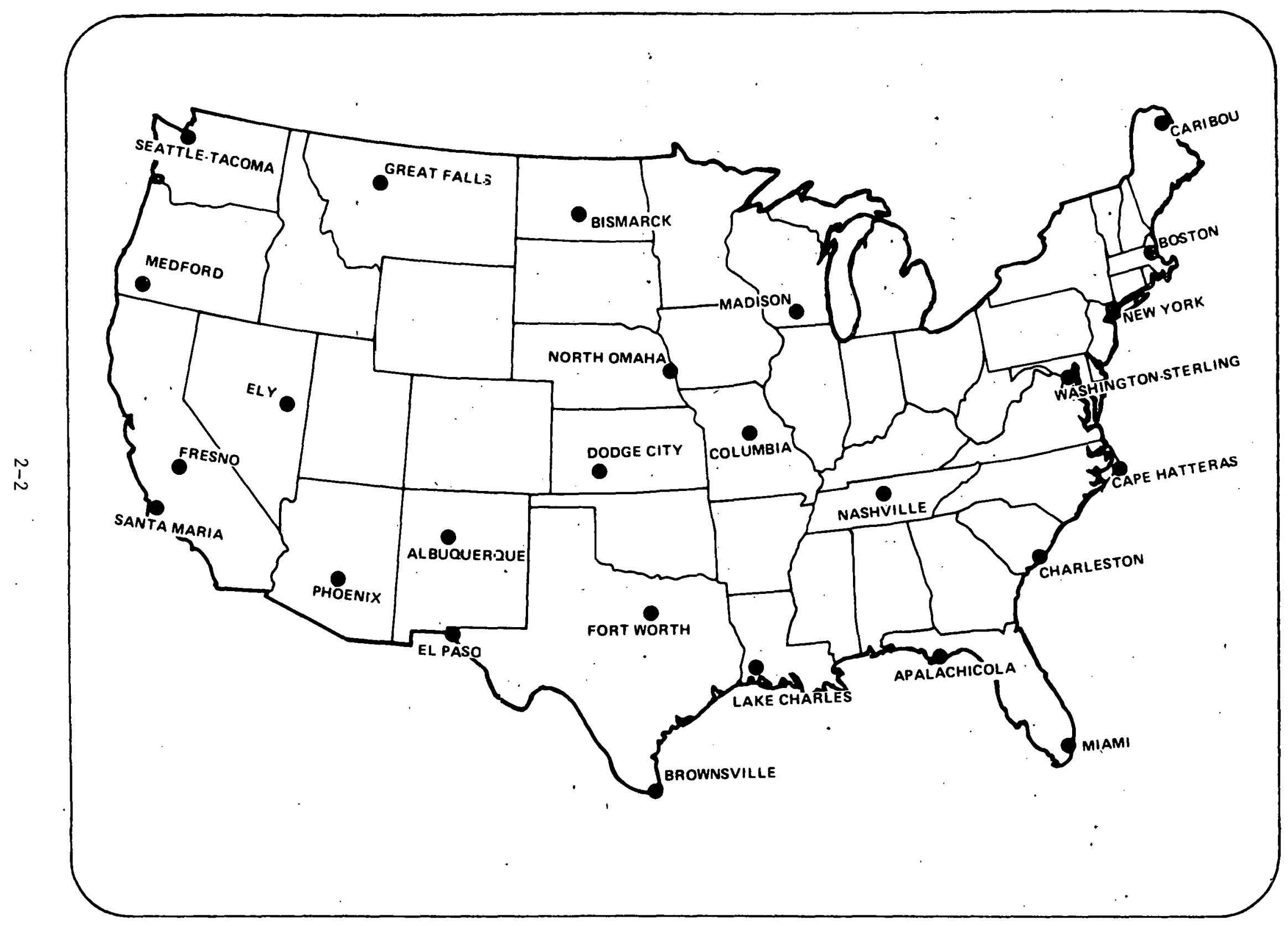

Figure 2-1. SOLMET HOURLY REPORTING STATIONS 
Note that diurnal wind power probabilities were also obtained. In addition to the above results, monthly averages of insolation and wind power were also obtained.

Presented in this volume are summary results - daily average values of insolation and wind power, by month. The statistical data are presented in Volume II.

\subsection{GUIDELINES AND APPROACH}

Statistical data derived from the study are obtained, essentially, by counting the number of occurrences of a specified condition being satisfied and dividing by the total number of trials. Empirical probabilities are constructed, by month, fo' daily average values of insolation and wind power, independently, equaling or exceeding each of several thresholds for $1,2, \ldots$, and 14 successive days. These are unconditional probabilities obtained from numbers of occurrences in given sample sizes. Using these probabilities, conditional probabilities are constructed (as discussed in the Technical Approach, Volume II) for events persisting at or above each of several thresholds for $2, \ldots$, and 14 days. Persistence is defined as an event continuing at or above a threshold for a certain number of days, once it has occurred at or above that threshold. For example, 2-day persistence is defined to mean an event continues to occur for the next day in sequence after it has occurred the first day.

The meteorological parameters considered in this study were solar radiation and wind power. Comparisons of the amounts of solar and wind energy available at specific locations can be made by. expressing these forms of energy in the same units. Simple calculations allow the basic comparison of the energy per unit area of wind perpendicular to the air flow and of solar radiation on a unit area of horizontal surface.

Insolation values were taken from the Standard Year Corrected field on the SOLMET set of data tapes since this field contains the rehabilitated serlally complete solar radiation data. These data are global radiation data incident on a horizontal surface based on a solar constant of $1377 \mathrm{Joules} /\left(\mathrm{m}^{2} \cdot \mathrm{s}\right)$; that 
is, total direct and diffuse radiation coming from all parts of the sky. Hourly insolation data are summed for the day, converted to watts $/ \mathrm{m}^{2}$, and divided by 24 (or by 8 if data was recorded every third hour) to obtain a dally average value. This is consistent with data published in climatic atlases of the United States by the NCC.

Wind power data are calculated from wind speed summarized records. The amount of wind power contained in the wind can be expressed as one-half the air density times the cube of the wind speed. Obviously, all the energy cannot be extracted from the wind since the airflow would stop. At best, windmill theory (ref. 1) shows that a maximum of $59.3 \%$ of the power contained in the wind can be extracted as useful kinetic energy. In this study, power contained in the wind is treated as a meteorological parameter and the problems of recovery, efficiency, etc., are left to the engineer. Wind power is calculated at each hourly observation in units of watts $/ \mathrm{m}^{2}$, summed for the day, and analogous to insolation, divided by the total number of daily observations to obtain a daily average value. Diurnal wind power variations are obtained in the same manner, where the basis is the total day. Note that recorded surface wind speed anemometer data have been adjusted to a "common" 10 meter height above the local terrain using the one-seventh power law, which is reasonable for the typically airport environment for the SOLMET data. One should also note that, in calculating wind power, wind speeds below 1.6 $\mathrm{m} / \mathrm{s}$ were considered to produce $\mathrm{nn}$ wind power and wind speeds abuve $14.2 \mathrm{~m} / \mathrm{s}$ were set to $14.2 \mathrm{~m} / \mathrm{s}$ to eliminate biasing daily averages when unusually, high or gusty winds were observed. 


\section{INSOLATION AND WIND POWER MONTHLY SUMMARIES}

Summary results were obtained for monthly average values of insolation and wind power. These values were essentially by-products of the statistical portion of the study and were assembled for a quick-look at comparative (or diverse) solar and wind conditions at the yarious SOLMET stations. Daily average values of insolation and wind power, for a particular month, were averaged over that month to obtain, essentially, the "average" daily average value for the month. Monthly averages were then averaged over the 20 years or so of records at each station to obtain average values for each month. These data were then combined in several different forms, as will be presented as follows, for an informative or comparative overview of average monthly solar and wind data.

Daily wind speed averages are not readily obtainable from daily average wind power due to the hourly variability. An estimate, however, of the daily average wind speed that would correspond, or relate, to the wind power presented, has been provided. Daily average wind speed associated with each wind power calculation was recorded for all years of data at several stations. By taking the mean of the distribution of daily average winds speeds at several power levels, a first order representation of wind speed to wind power can be obtained, as shown in Figure 3-1.

Solar energy on a horizontal surface generally increases from the northerly to the southerly latitudes, and varies from a peak in the summer months to lows in the winter months. (These variations are not as pronounced for a tilted surface.) Wind power, on the other hand, is quite variable, with the coastal regions affected by local exposure. Wind power is usually highest in the spring, and lower in summer than in fall and winter.

Monthly average values, of daily average solar insolation and wind power were obtained for each of the SOLMET stations. (Note that daily average totals can be obtained by multiplying by 24.) Presented in Figures 3-2 through 3-13 are maps of the United States showing the available solar and wind power at

$$
3-1
$$




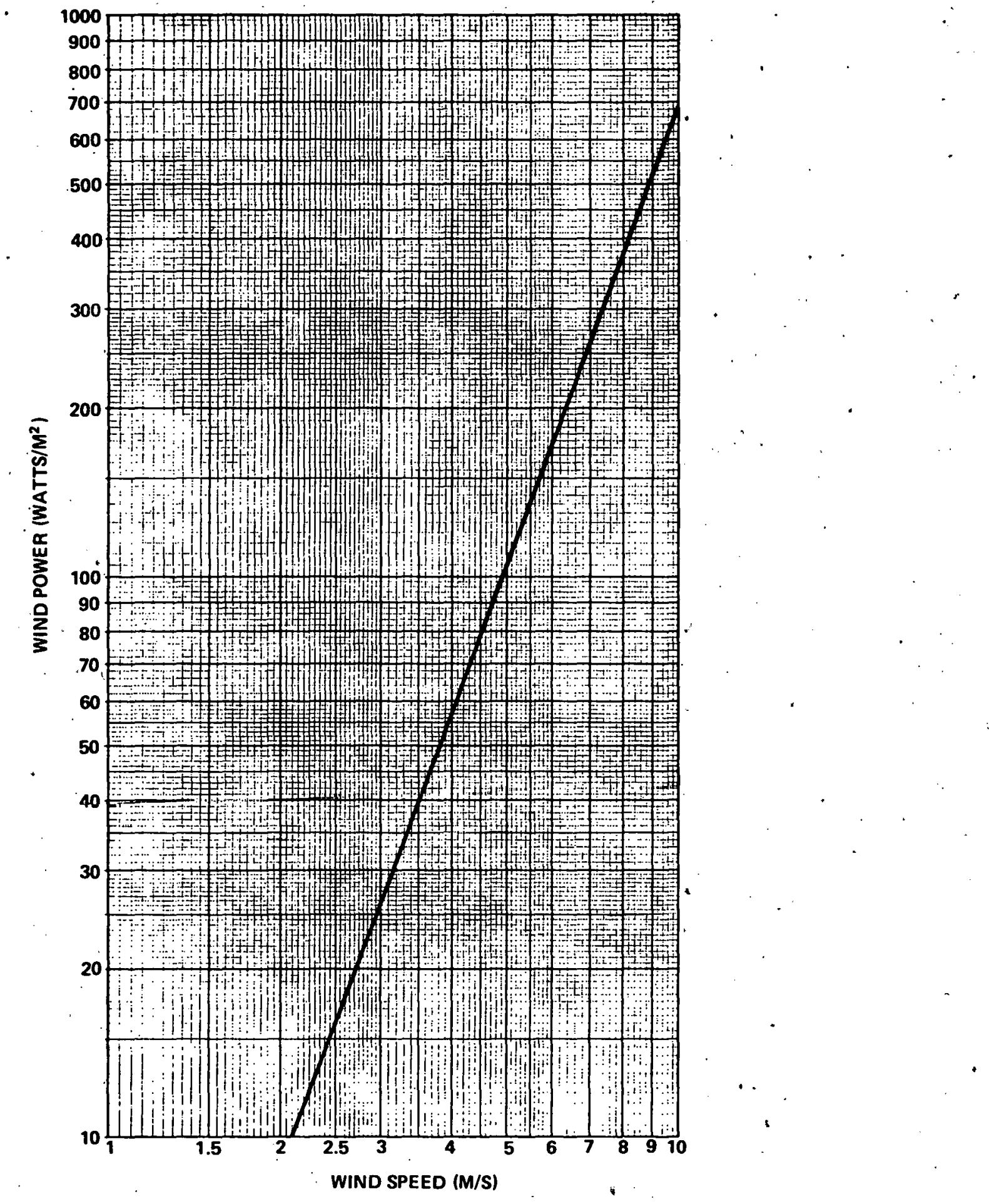

Figure 3-1. DAILY AVERAGE WIND POWER VS. DAILY AVERAGE WIND SPEED 


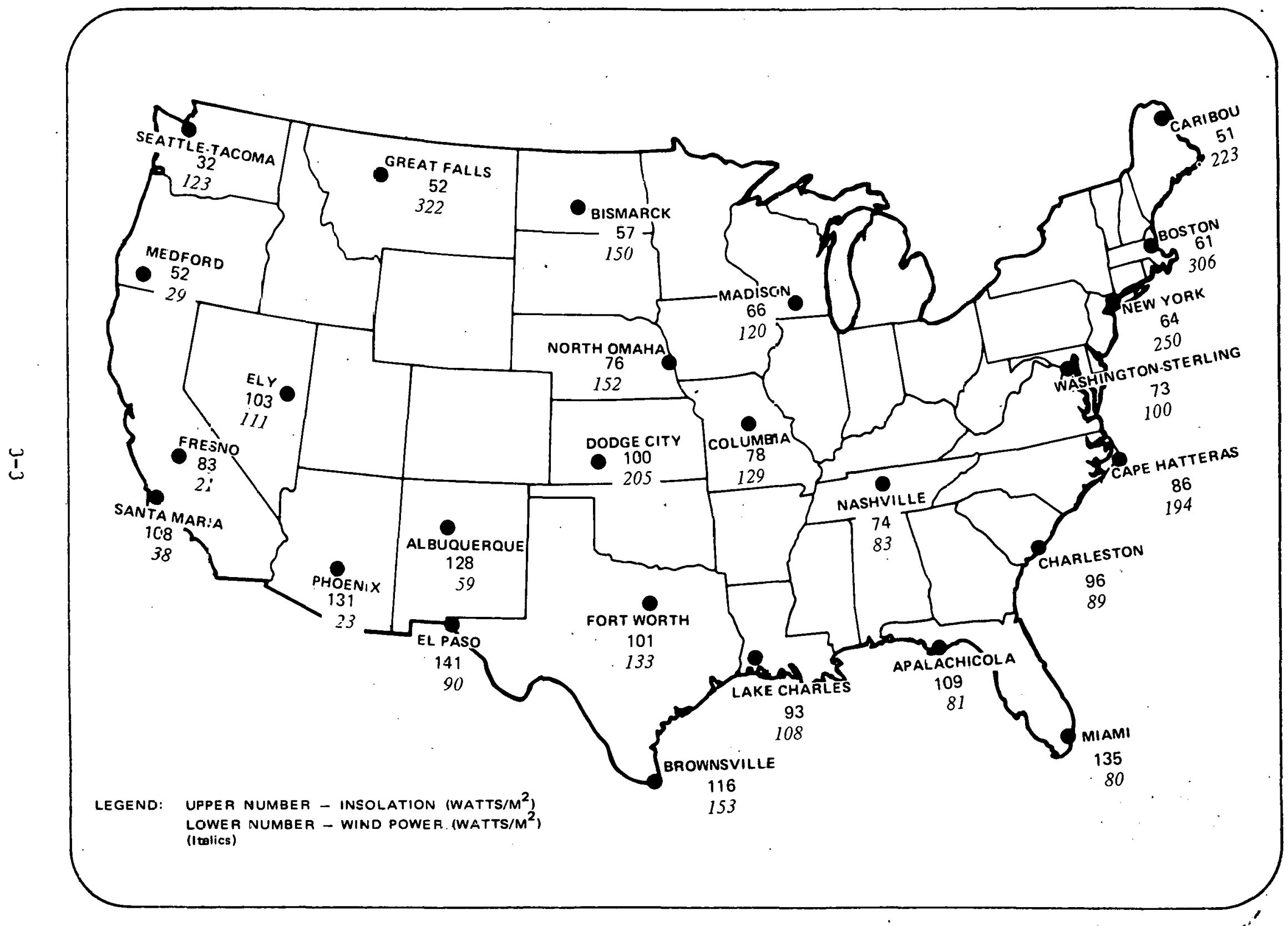

Figure 3-2. AVAILABLE SOLAR AND WIND POWER - JANUARY 


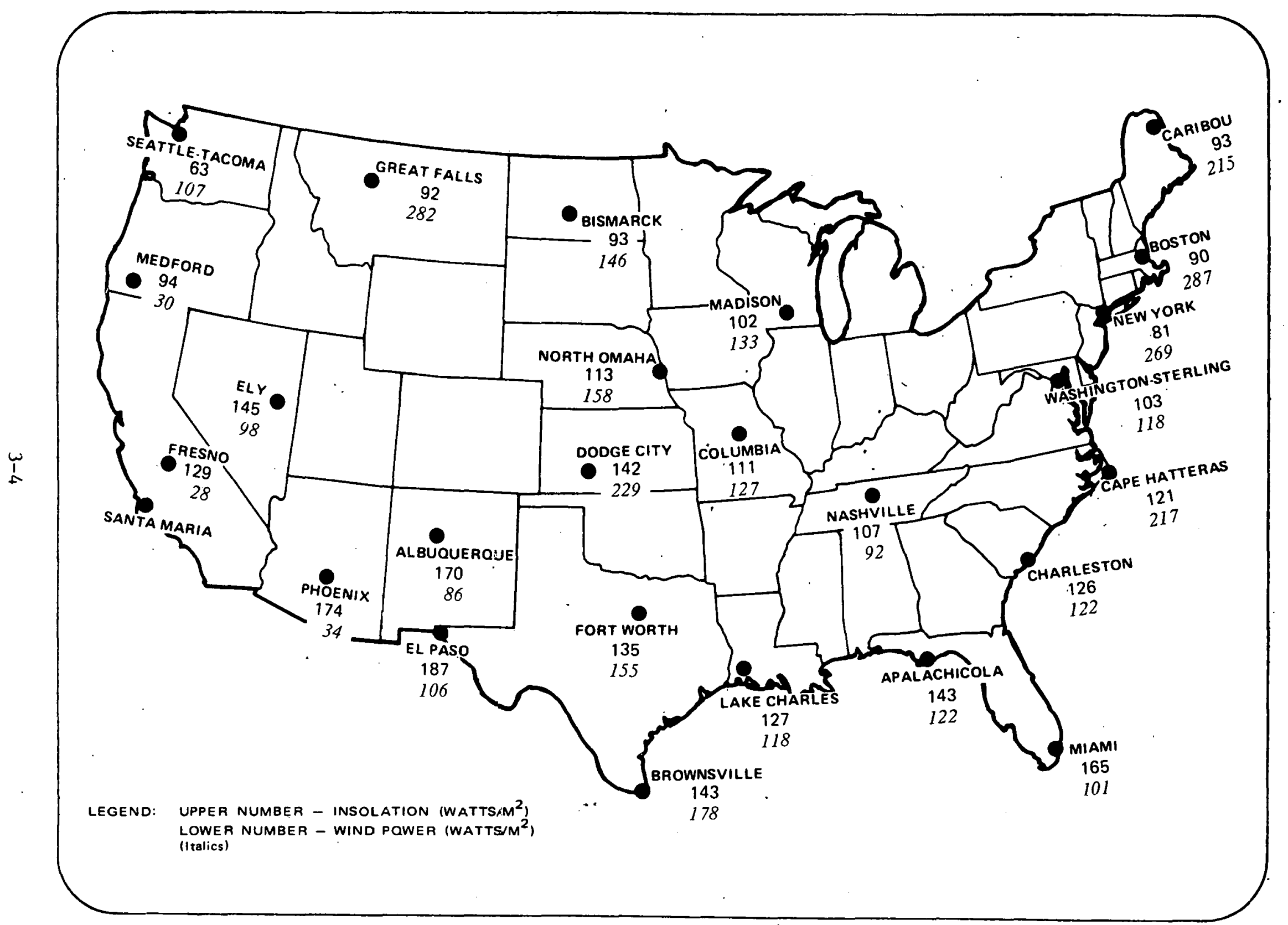

Figure 3-3. AVAILABLE SOLAR AND WIND POWER - FEBRUARY 


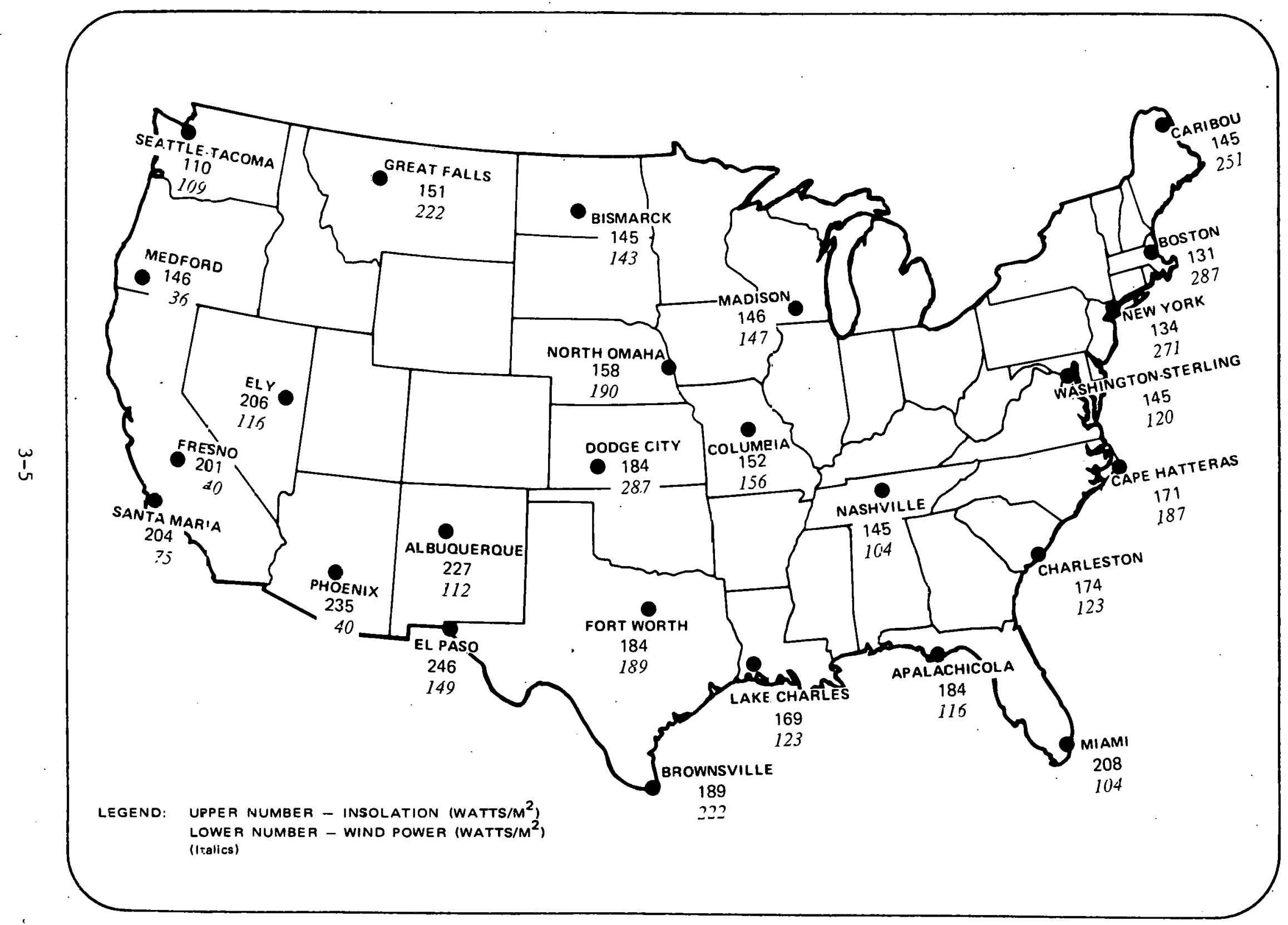

Figure 3-4. AVAILABLE SOLAR AND WIND POWER - MARCH 


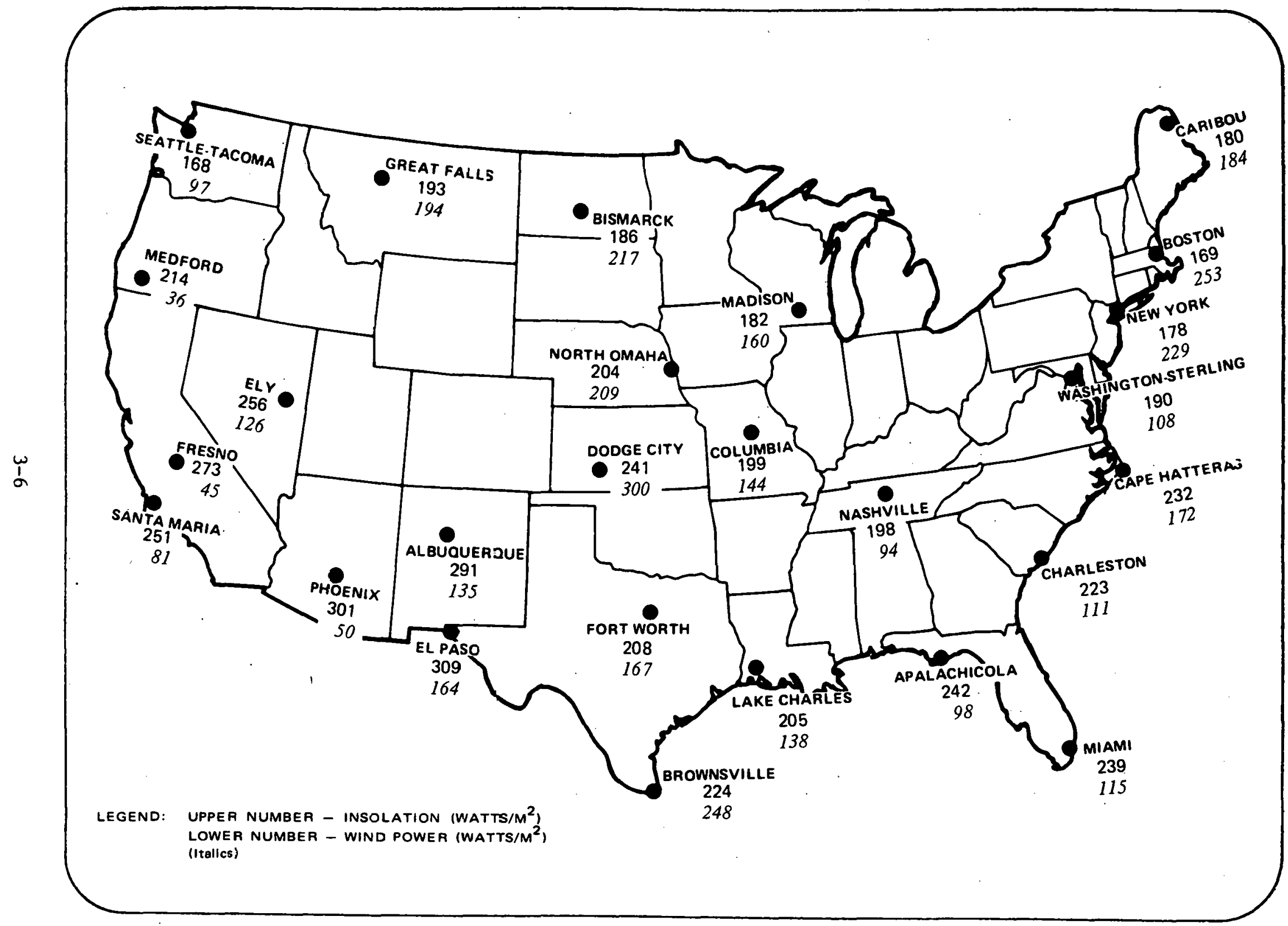

Figure 3-5. AVAILABLE SOLAR AND WIND POWER - APRIL 


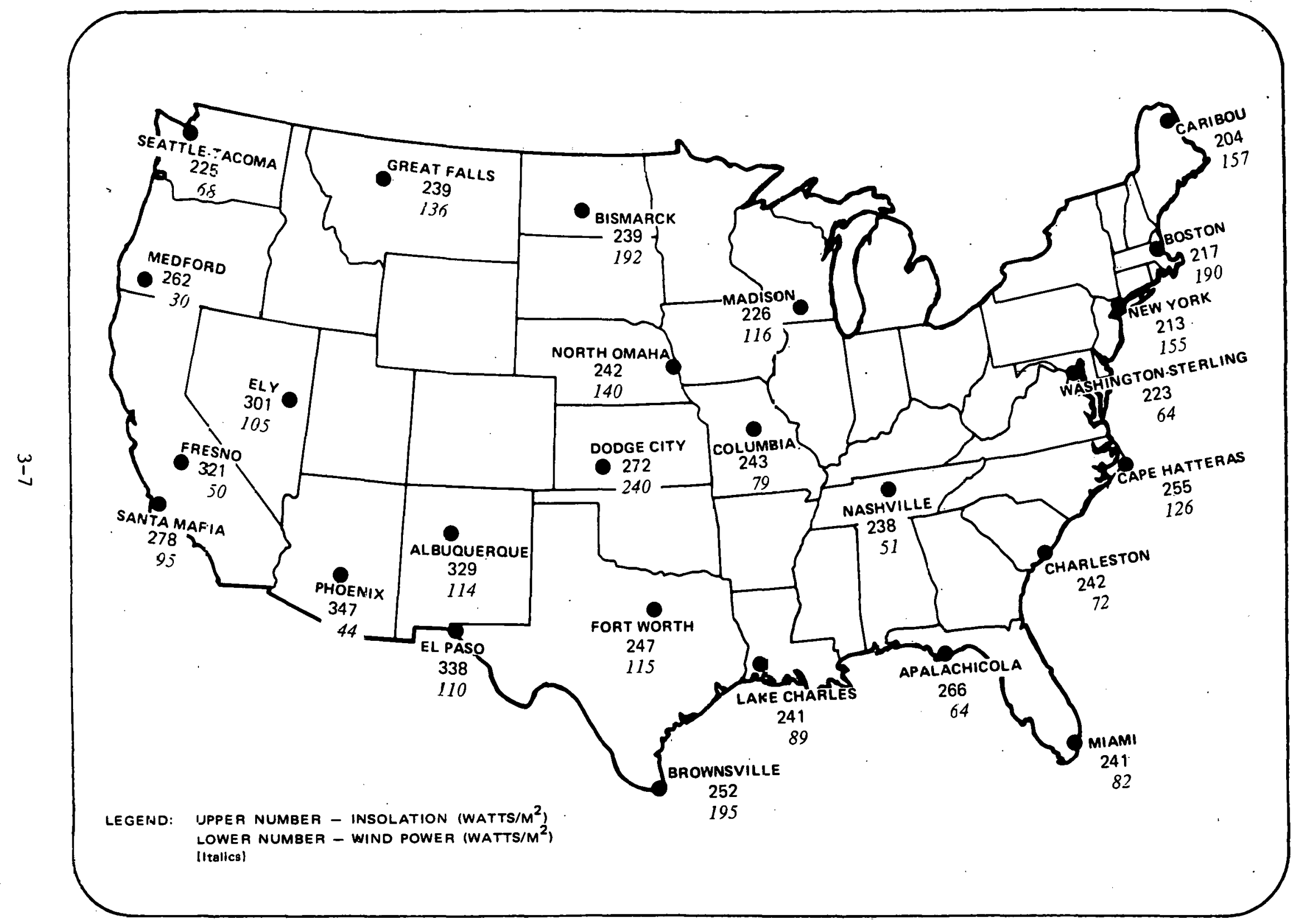

Figure 3-6. AVAILABLE SOLAR, AND WIND POWER - MAY 


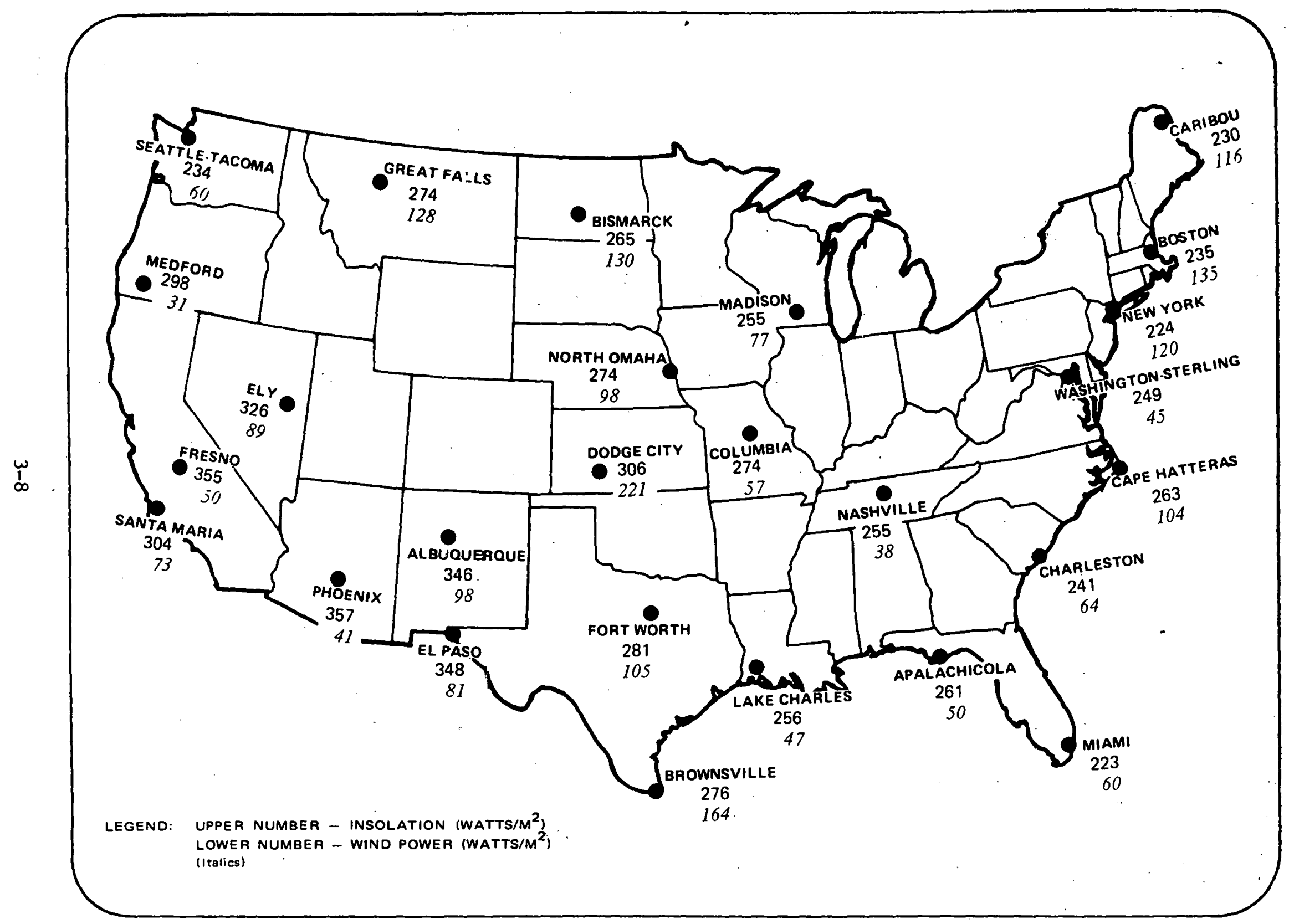

Figure 3-7. AVAILABLE SOLAR AND WIND POWER - JUNE 


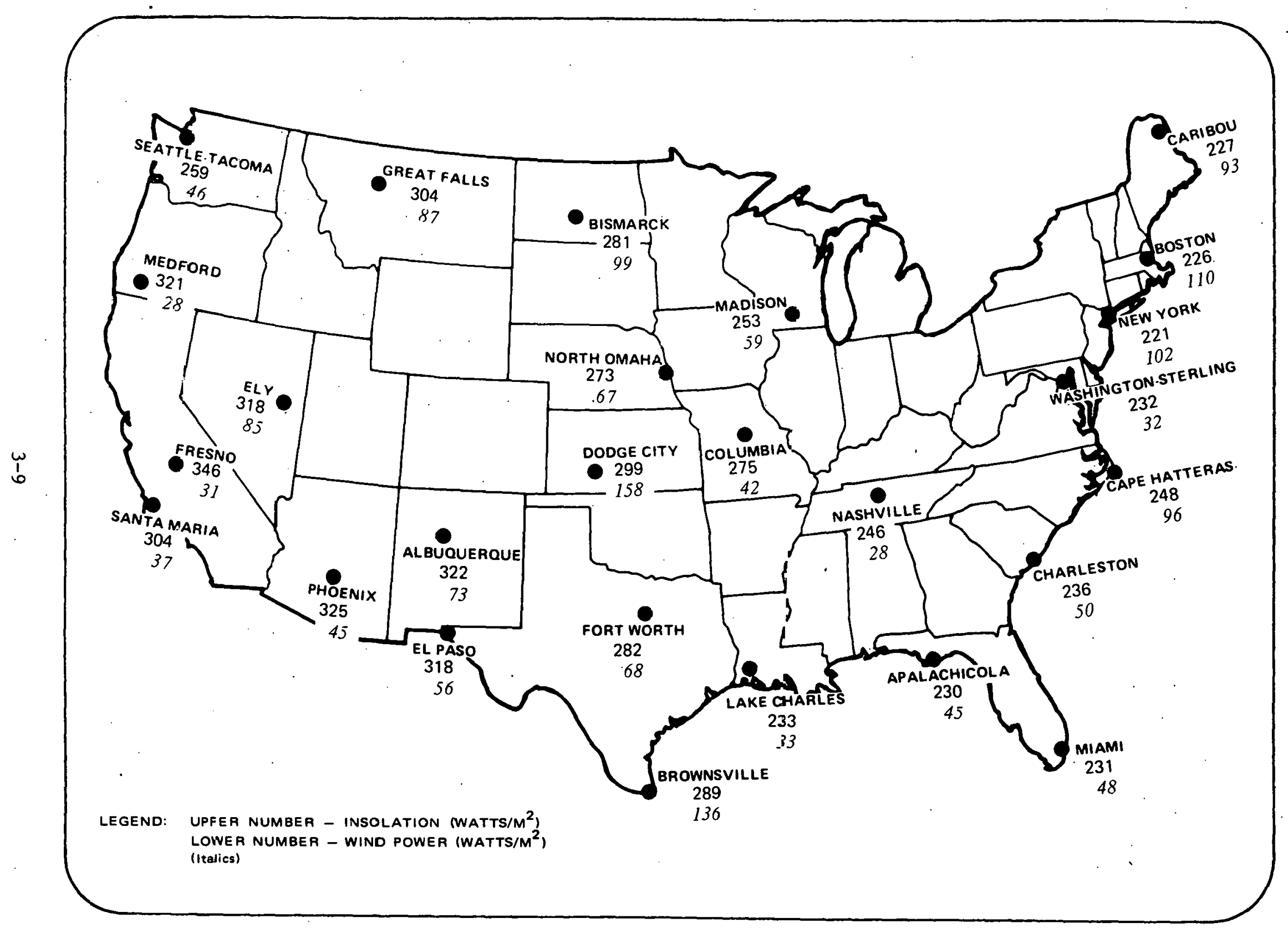

Figure 3-8. AVAILABLE SOLAR AND WIND POWER - JULY 


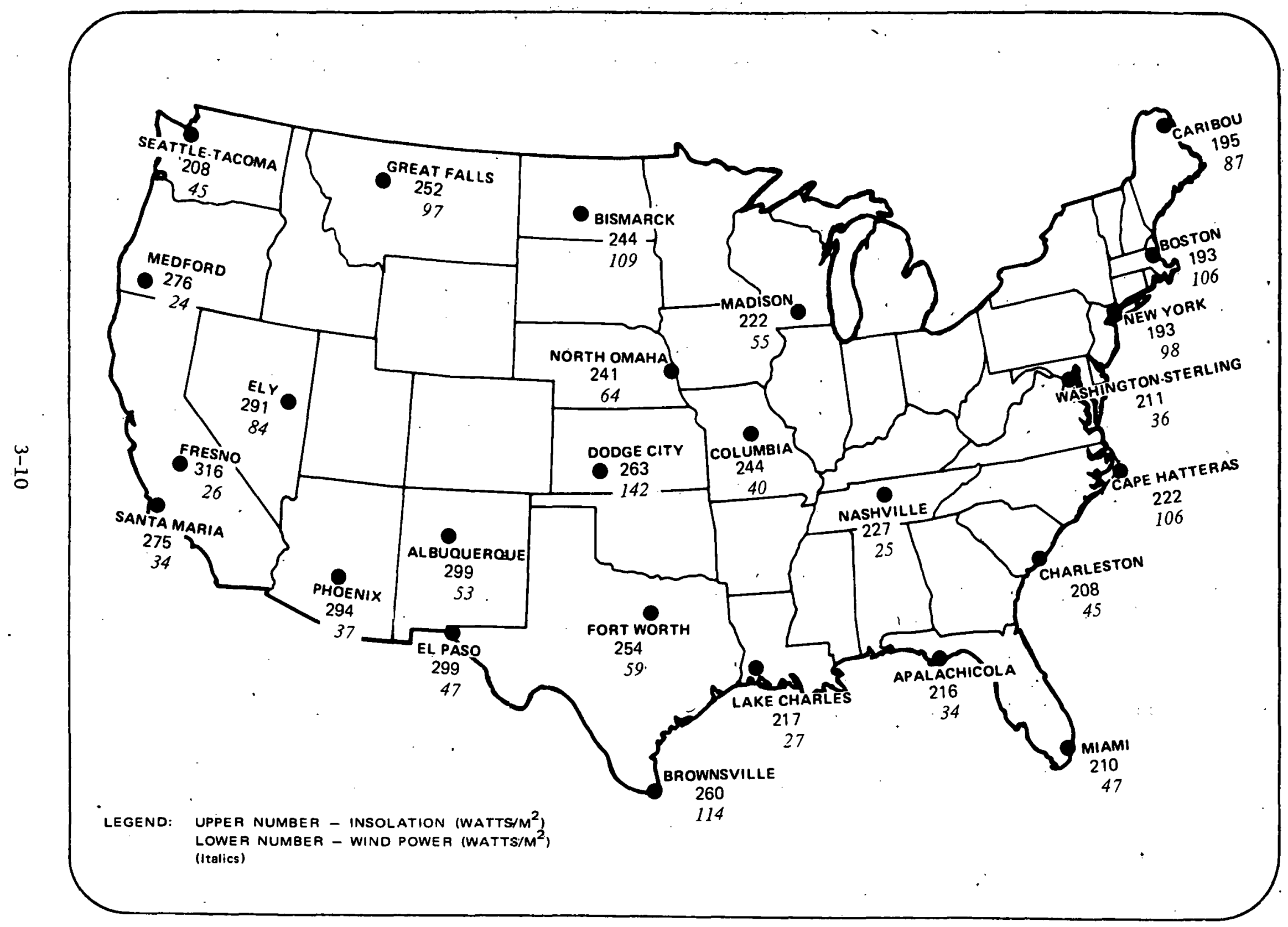

Figure 3-9. AVAILABLE SOLAR AND WIND POWER - AUGUST 


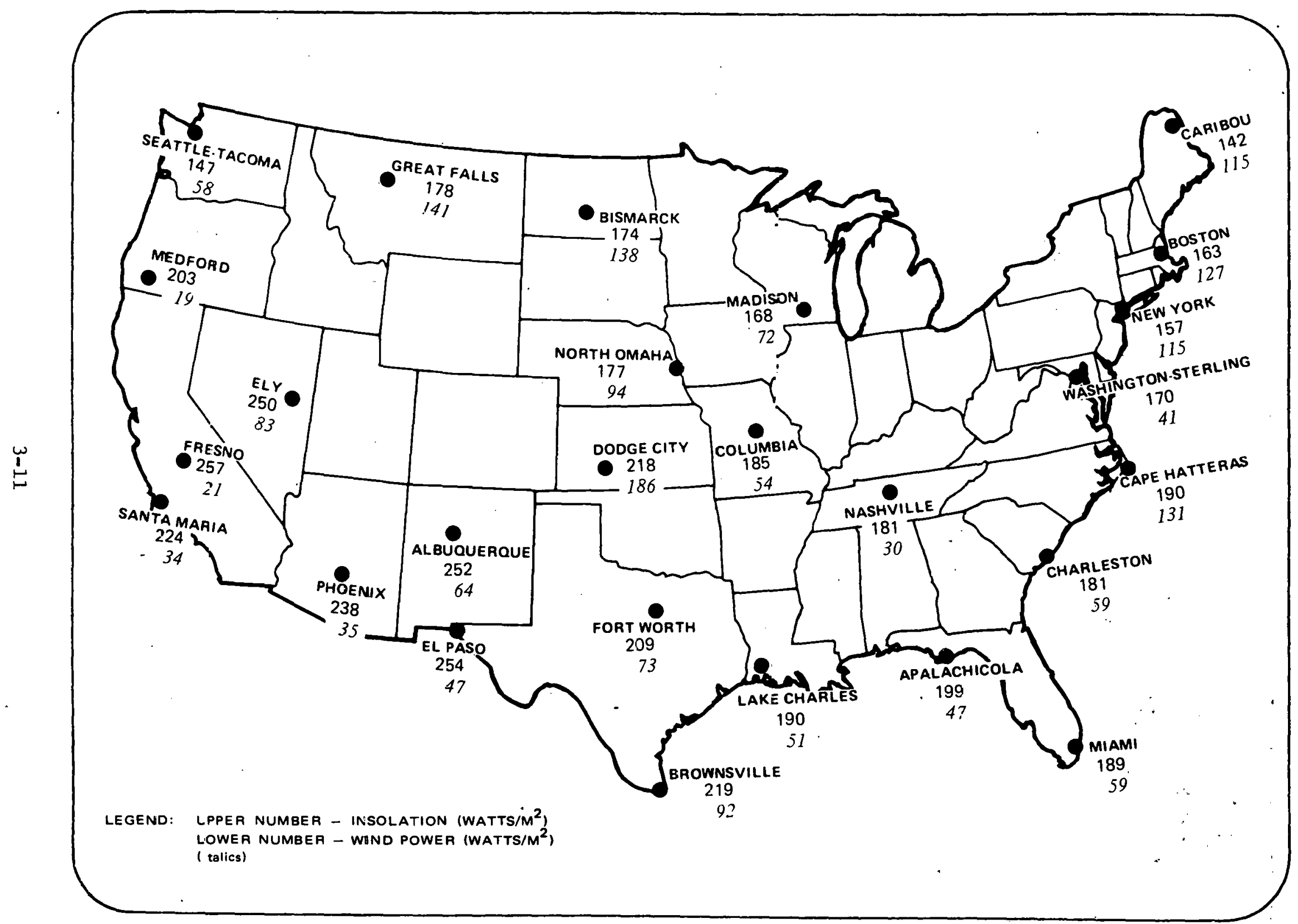

Figure 3-10. AVAILABLE SOLAR AND WIND POWER - SEPTEMBER 


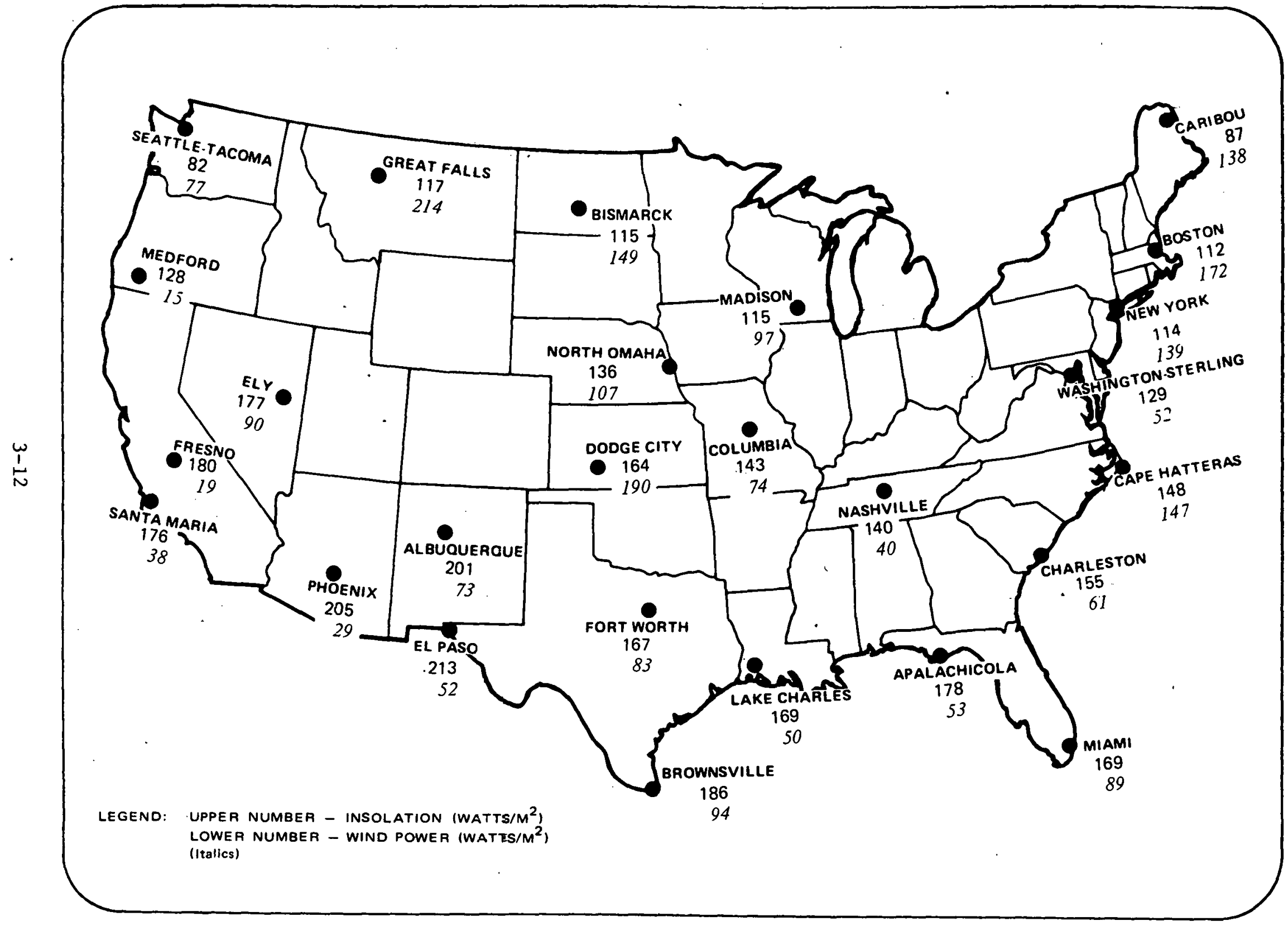

Figure 3-11. AVAILABLE SOLAR AND WIND POWER - OCTOBER 


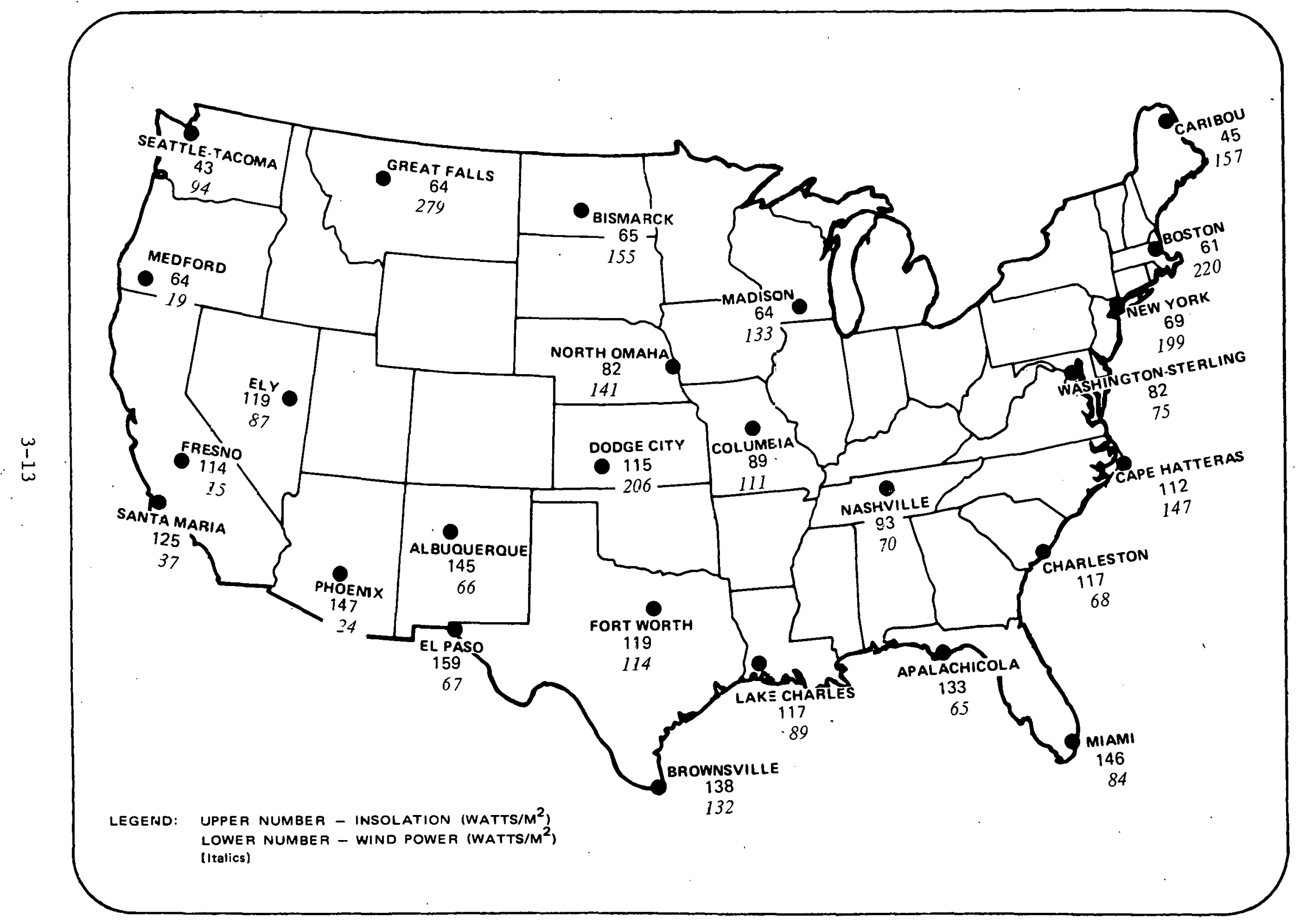

Figure 3-12. AVAILABLE SOLAR AND WIND POWER - NOVEMBER 


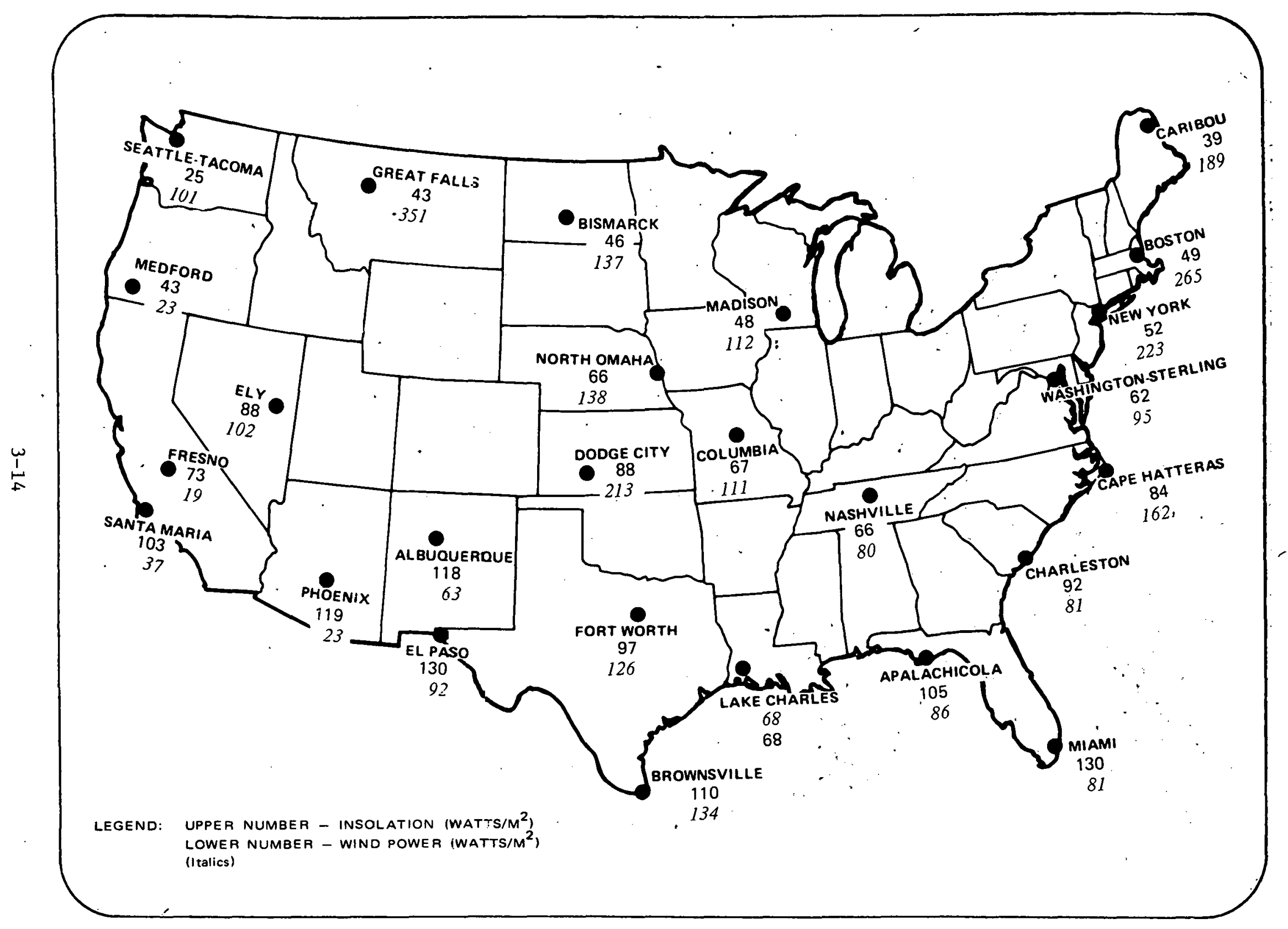

Figure 3-13. AVAILABLE SOLAR AND WIND POWER - DECEMBER 
each site, by month. (One must be reminded that the term available refers to. the power contained in the wind, as discussed in Section II.) The lower number (in italics) at each site represents the calculated daily average wind power for that month, while the upper number is insolation. The data points, for this study, are too scattered to present meaningful iso-lines. However, one can still visualize the interstation variability.

It is of interest to look at the same information, with the addition of diurnal variations of wind, as a function of the months of the year, for each station. These data, together with the sum of insolation and wind power to indicate total available combined energy, are presented in Figures 3-14 through 3-39. Specifically, daily average values are presented by month and annual for insolation, wind power (day), wind power (night), wind power (total day) and the sum of insolation plus wind power (tota1). These data are presented for each SOLMET station in alphabetic order. The month Roman numeral code is as follows: I Is January, ...., XII = December and XIII = annual average. Note, for the diurnal wind power variations, that at most sites daytime wind power has the greater annual average. At several of these locations, however, it can be seen that nighttime wind averages are higher in the winter months. Energy demand curves can be superimposed over the combined, or total, energy curves to aid in identifying areas that warrant further investigation for possible hybrid energy applications.

The data were also combined in seasonal form for considerations of annual variability of available power that could possibly be applied to electricity demands. Daily averages were prepared for insolation and wind power, along with diurnal wind power variations, by seasum and annual. These data are presented in Table 3-1 for each station in alphabetic order. The heading codes used are WI-winter, SP-spring, SU-summer, FA-fall and AN-annual average. Other codes are self-explanatory. 


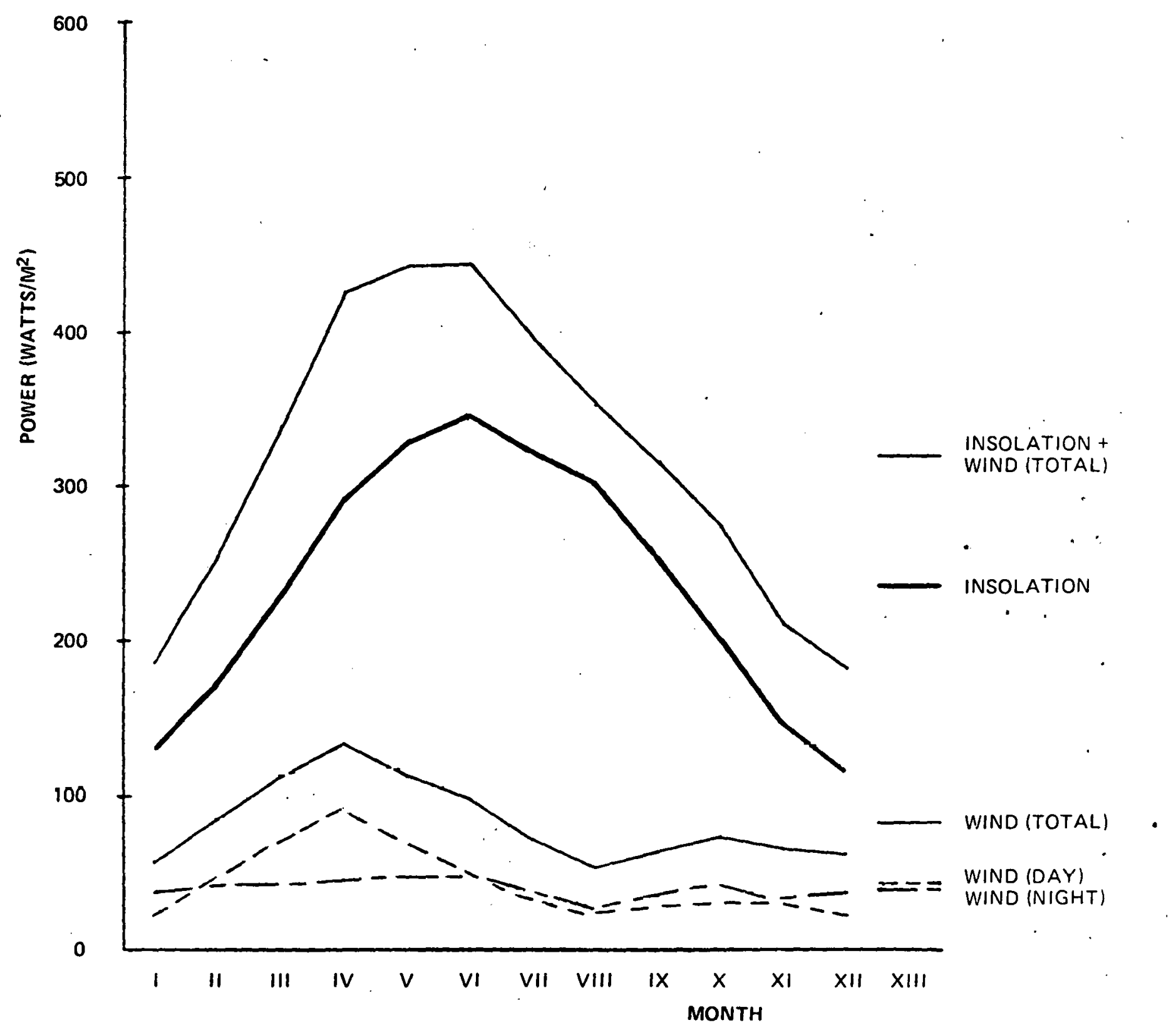

Figure 3-14. DAILY AVERAGE INSOLATION AND WIND POWER, BY MONTH AND ANNUAL ALBUQUERQUE, NM 


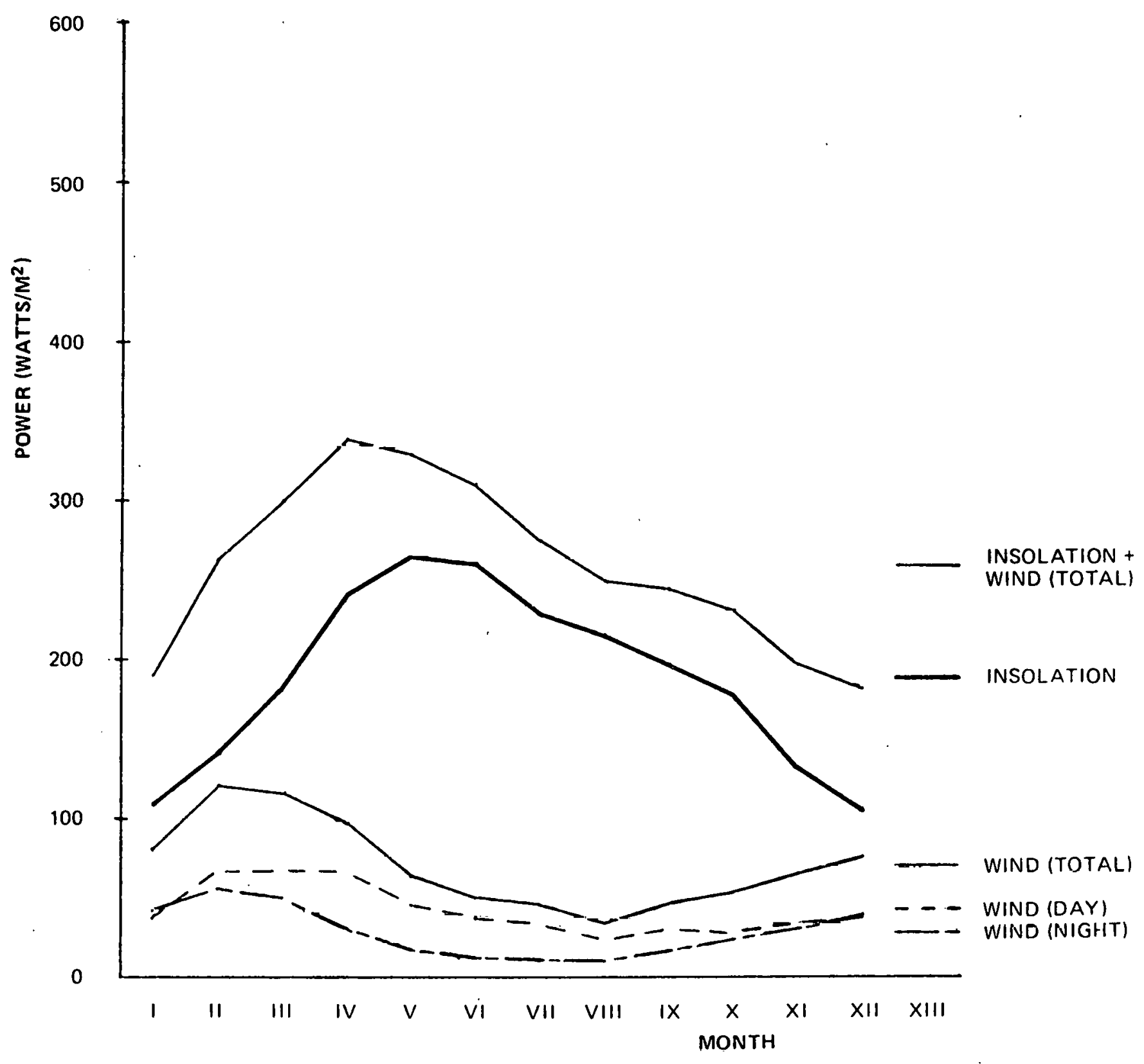

Figure 3-15. DAILY AVERAGL INSOLATION AND WIND POWER, BY MONTH AND ANNIAL APALACHICOLA, FL 


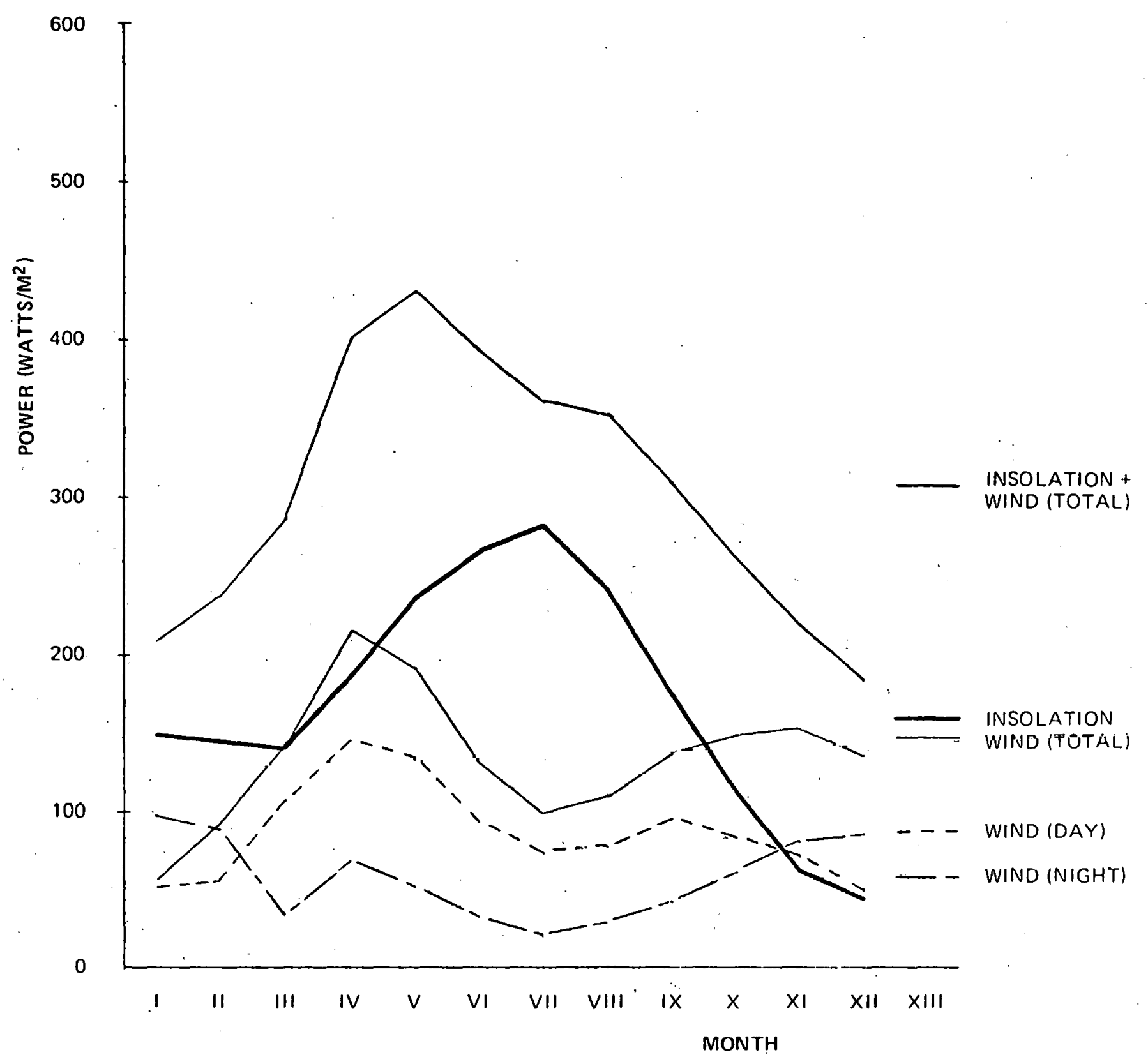

Figure 3-16. DAILY AVERAGE INSOLATION AND WIND POWER, BY MONTH AND ANNUAL BISMARCK, ND 


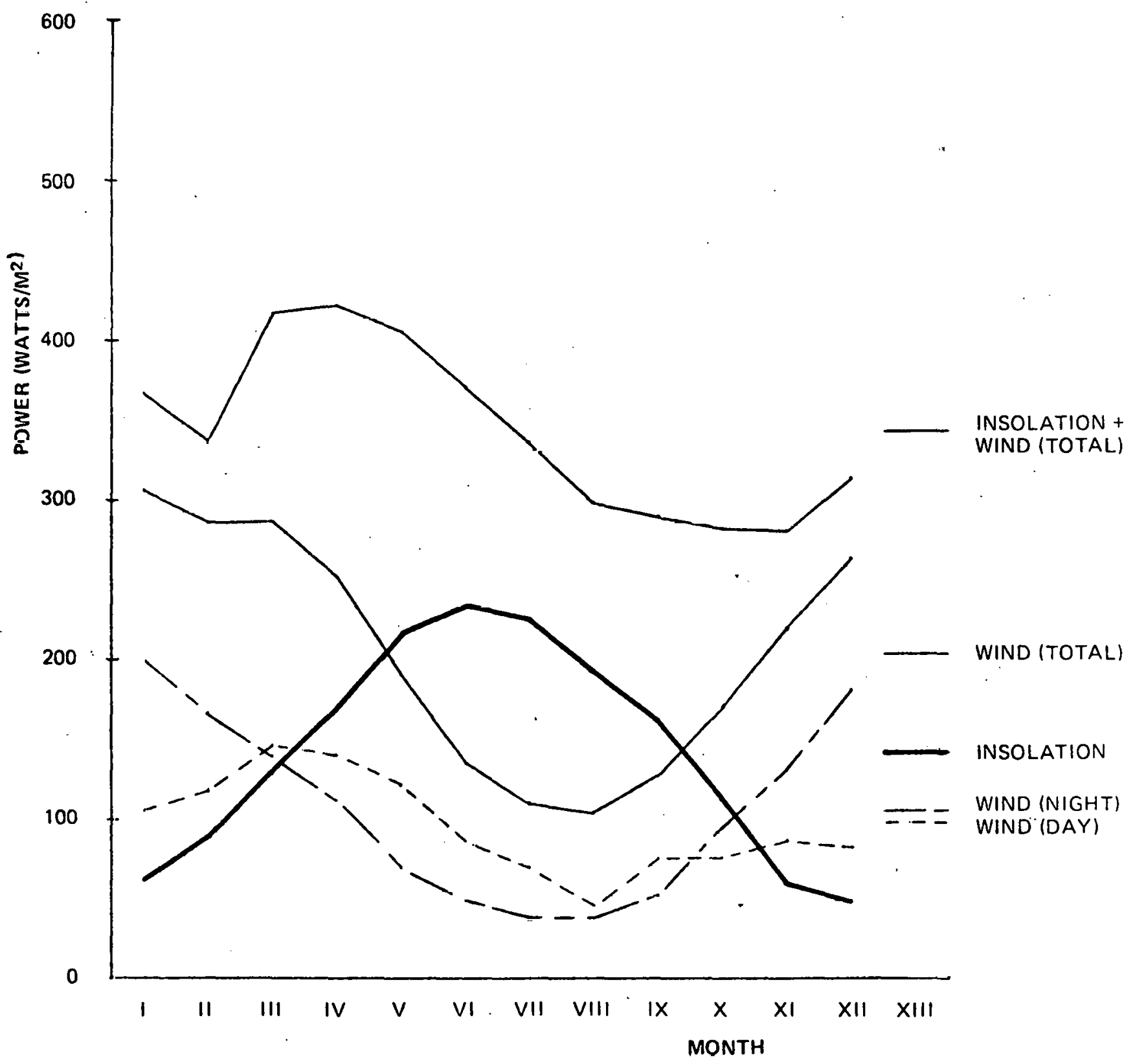

Figure 3-17. DAILY AVERAGE INSOLATION AND WIND POWER, BY MONTH AND ANNUAL BOSTON, MA 


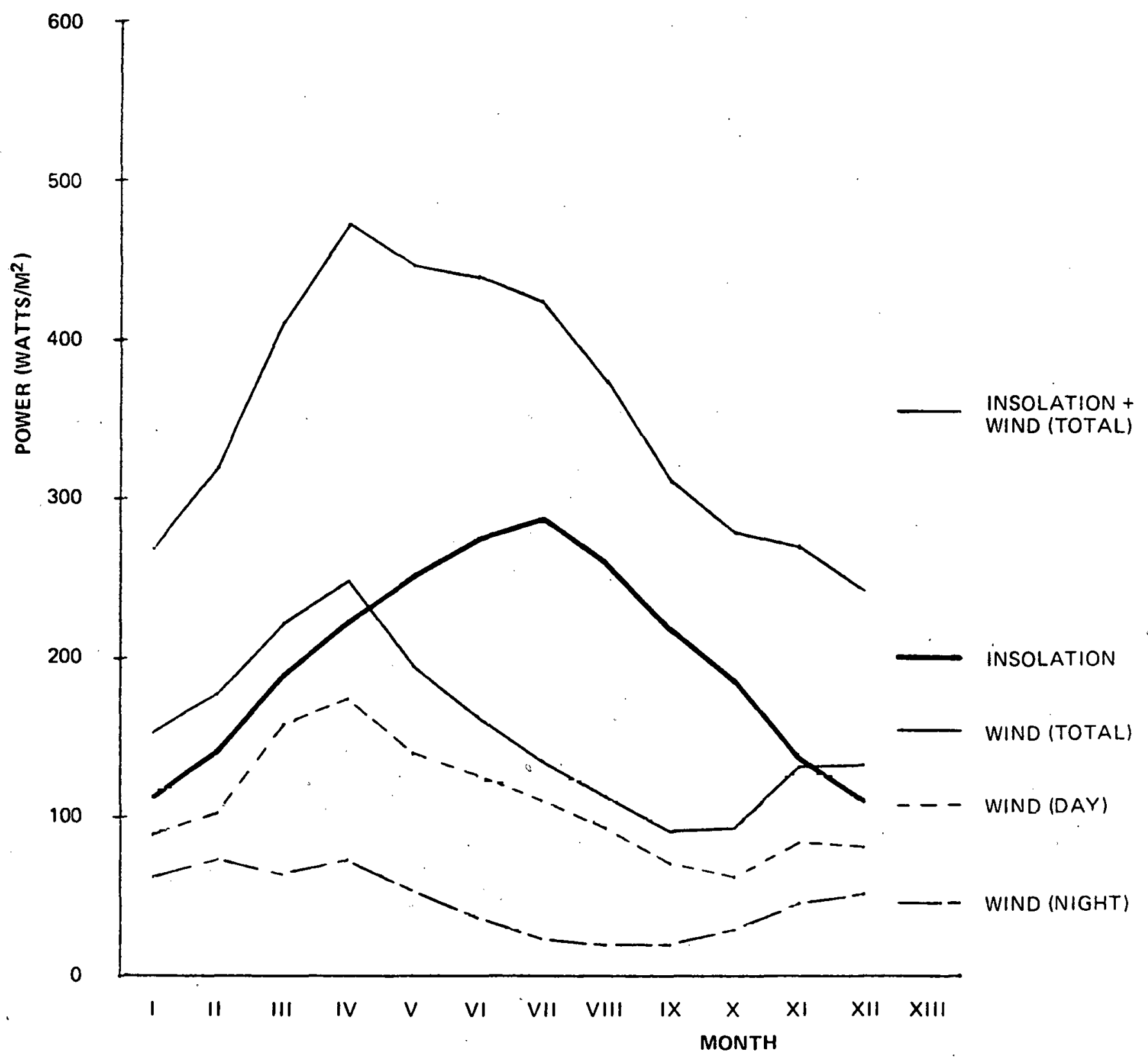

Figure 3-18. DAILY AVERAGE INSOLATION AND WIND POWER, BY MONTH AND ANNUAL BROWNSVILLE, TX 


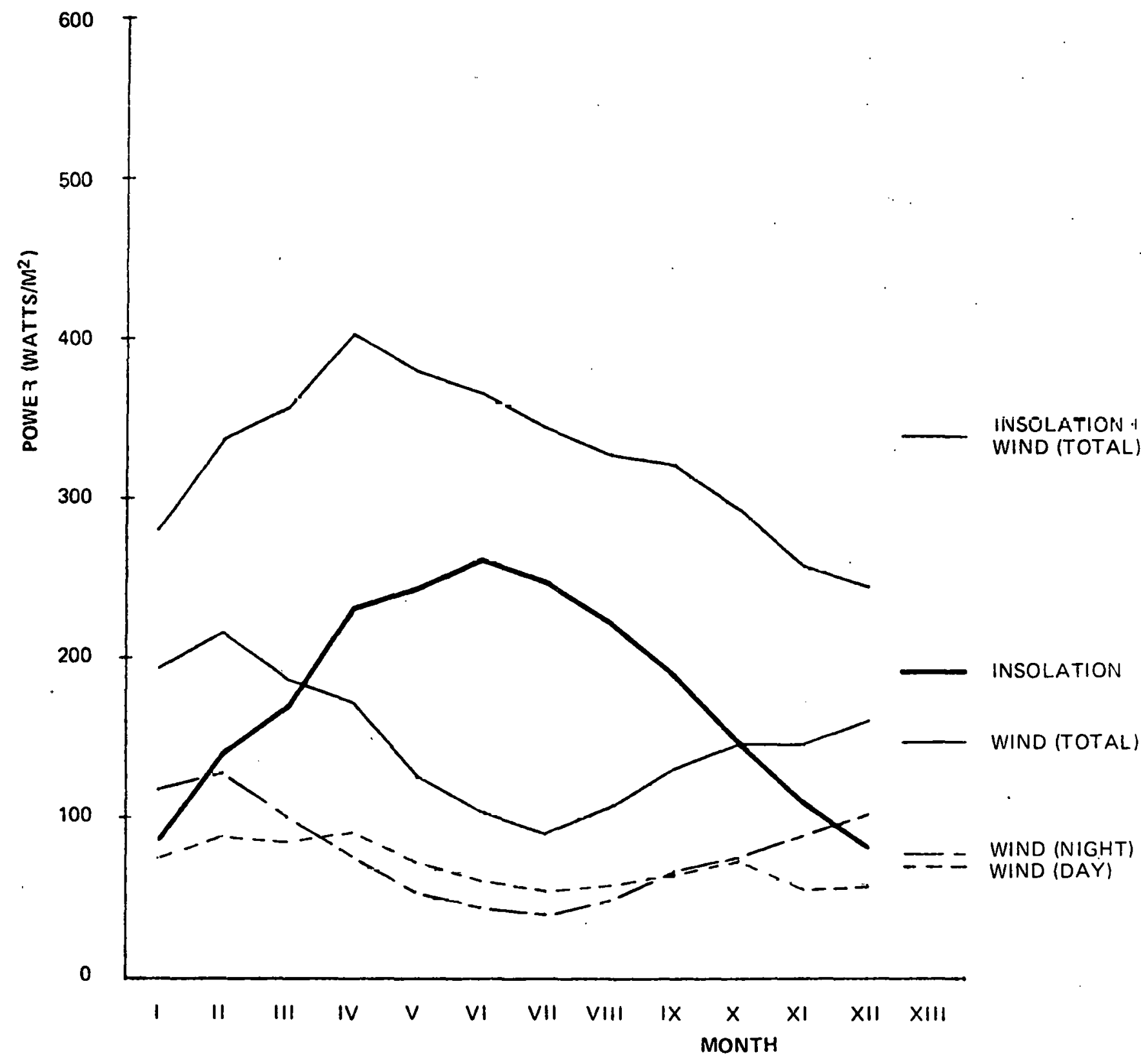

Figure 3-19. DAILY AVERAGF INSOLATION AND WIND POWER, BY MONTH AND ANNUAL CAPE HATTERAS, NC 


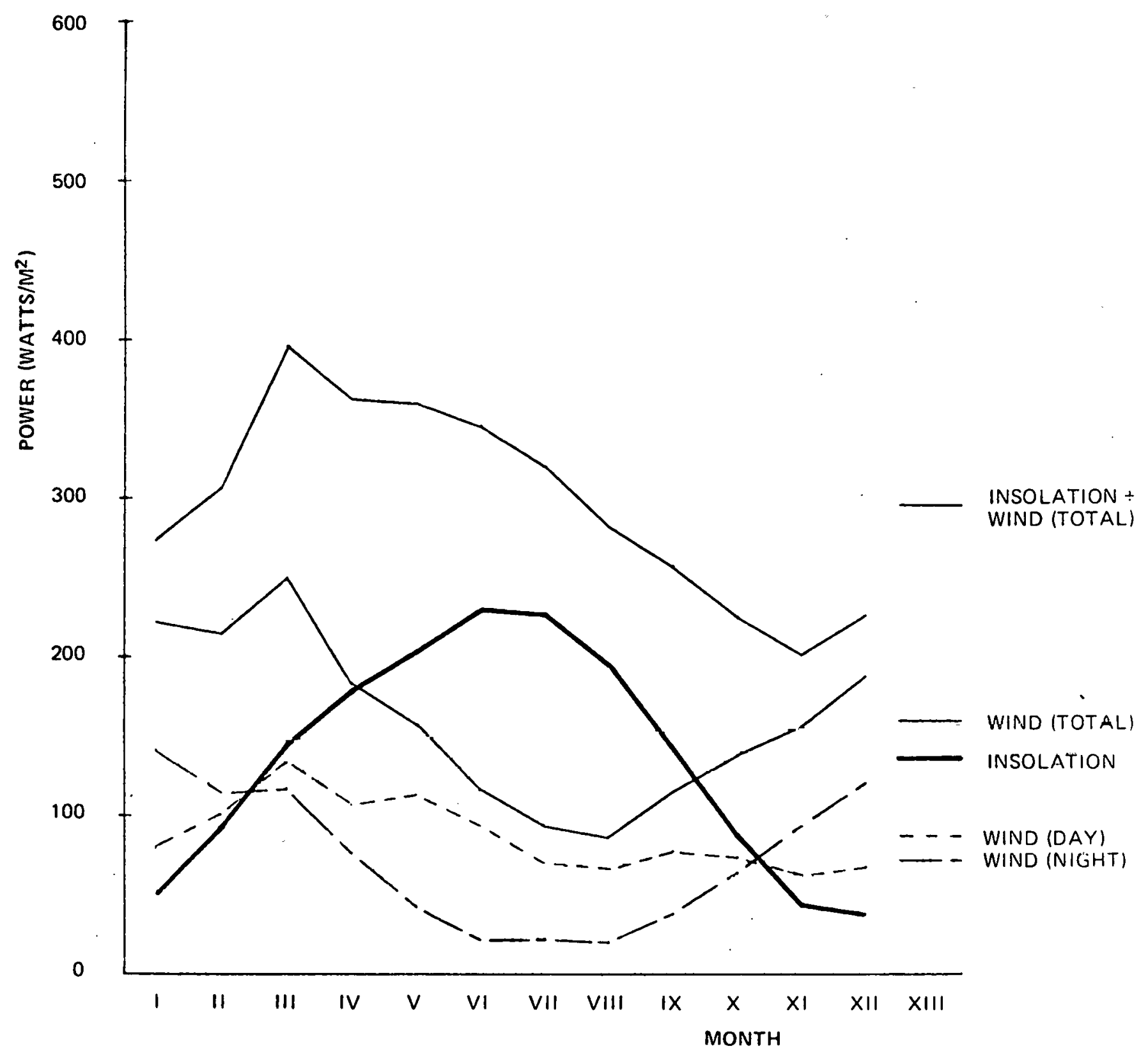

Figure 3-20. DAILY AVERAGE INSOLATION AND WIND POWER, BY MONTH AND ANNUAL CARIBOU, ME 


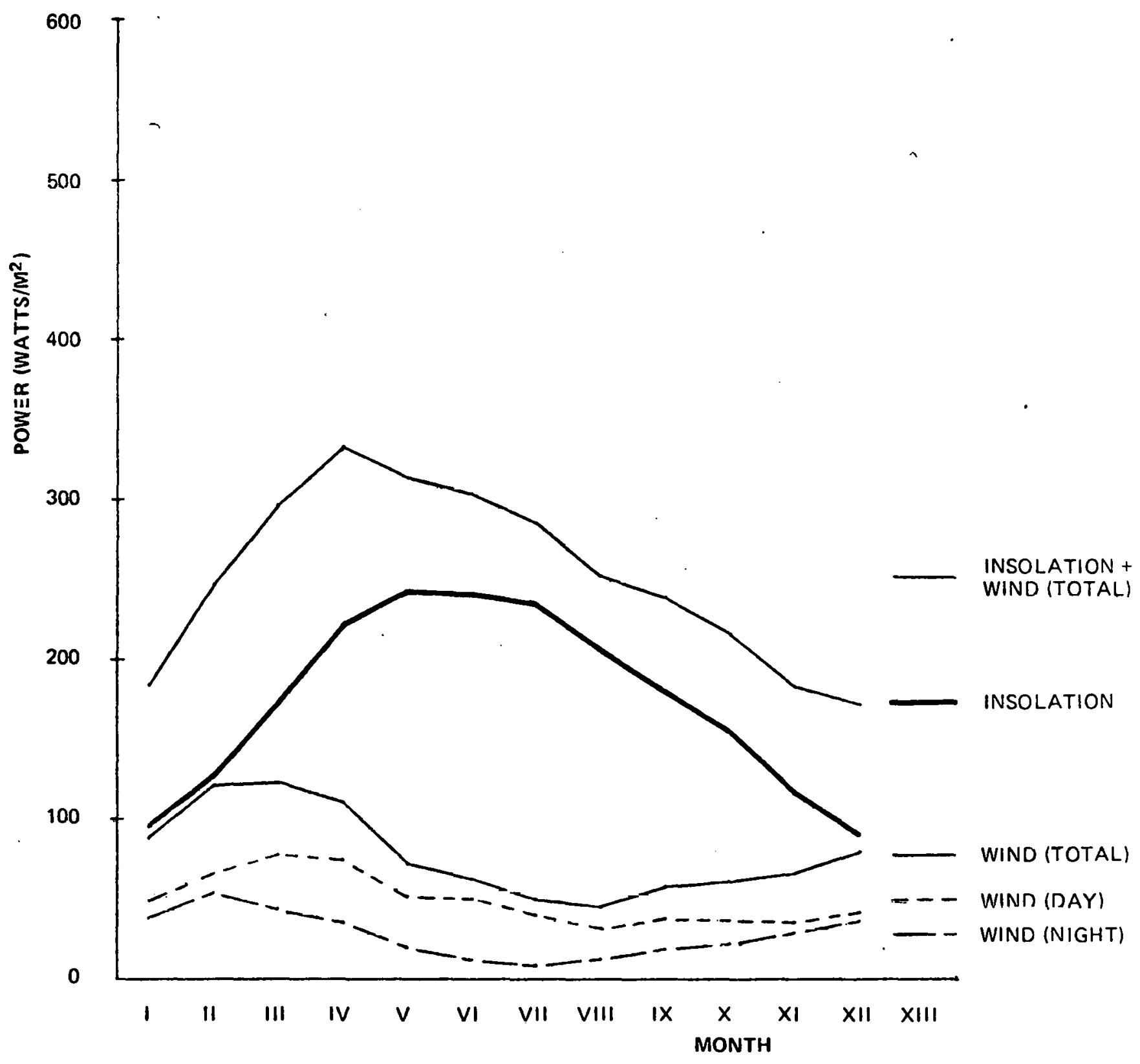

Figure 3-21. DAILY AVERAGE INSOLATION AND WIND POWER, BY MONTH AND ANNUAL CHARLESTON, SC 


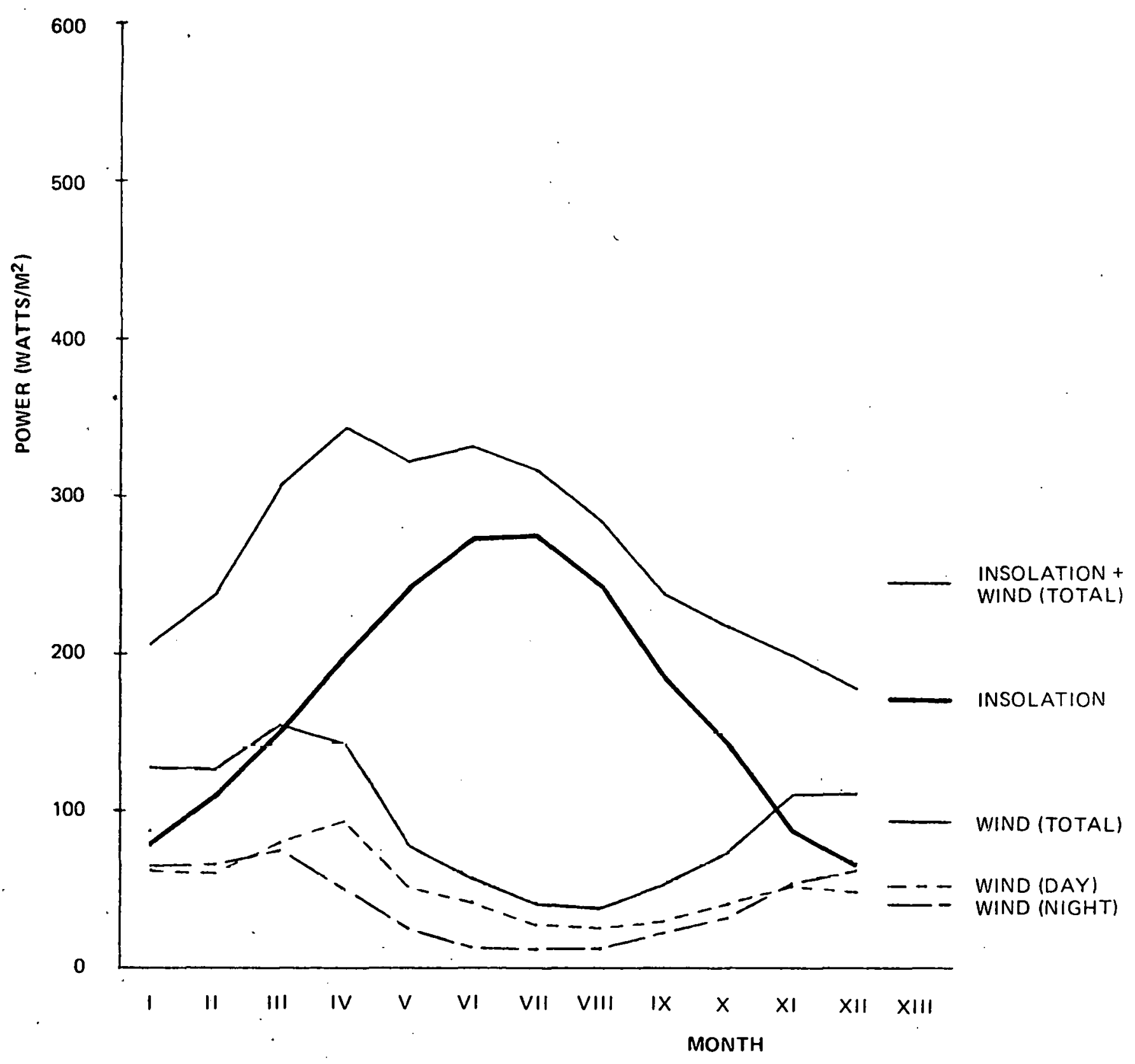

Figure 3-22. DAILY AVERAGE INSOLATION AND WIND POWER, BY MONTH AND ANNUAL -COLUMBIA, MO 


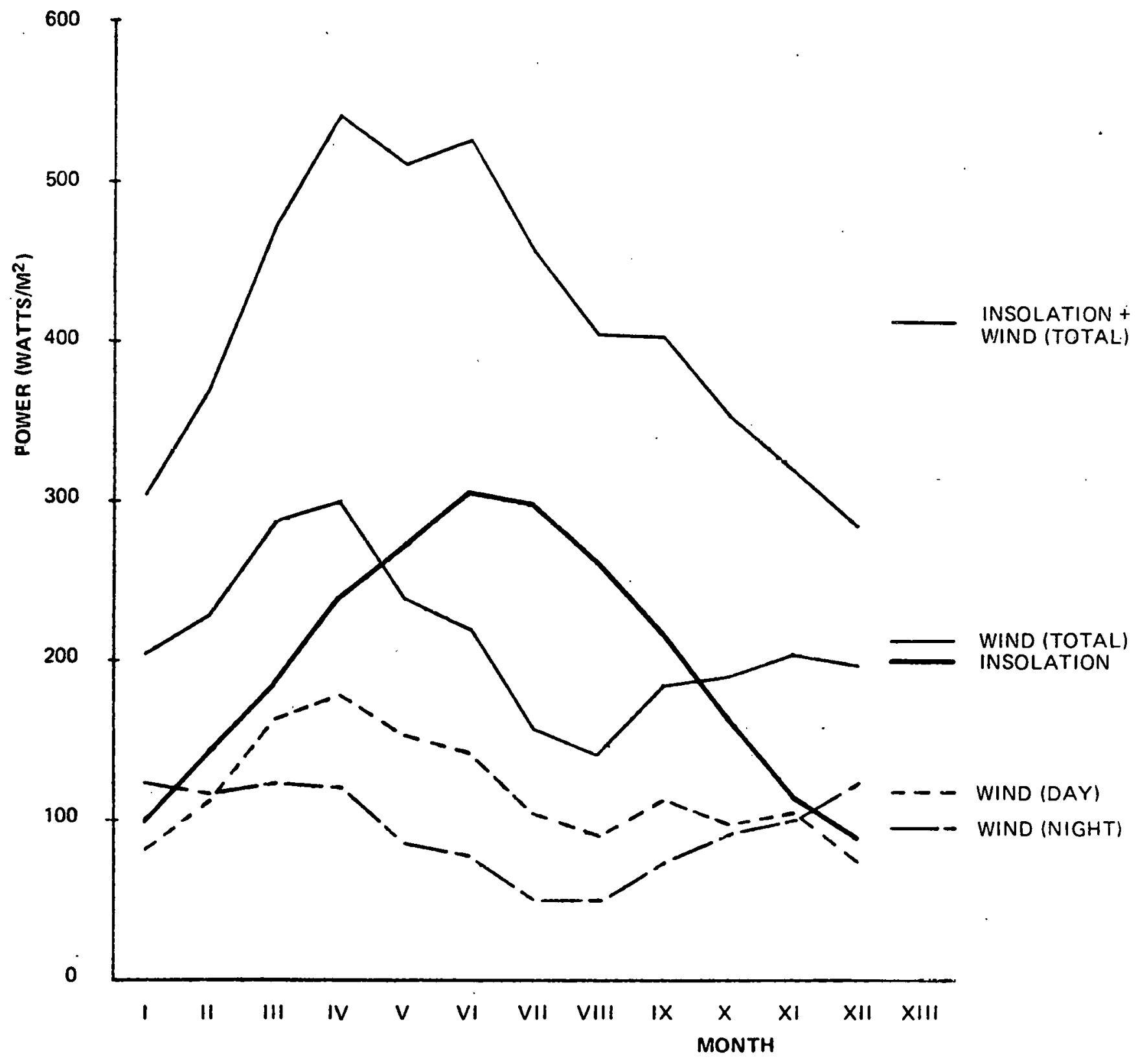

Figure 3-23. DAILY AVERAGE INSOLATION AND WIND POWFR, BY MONTH AND ANNUAL DODGE CITY, KS 


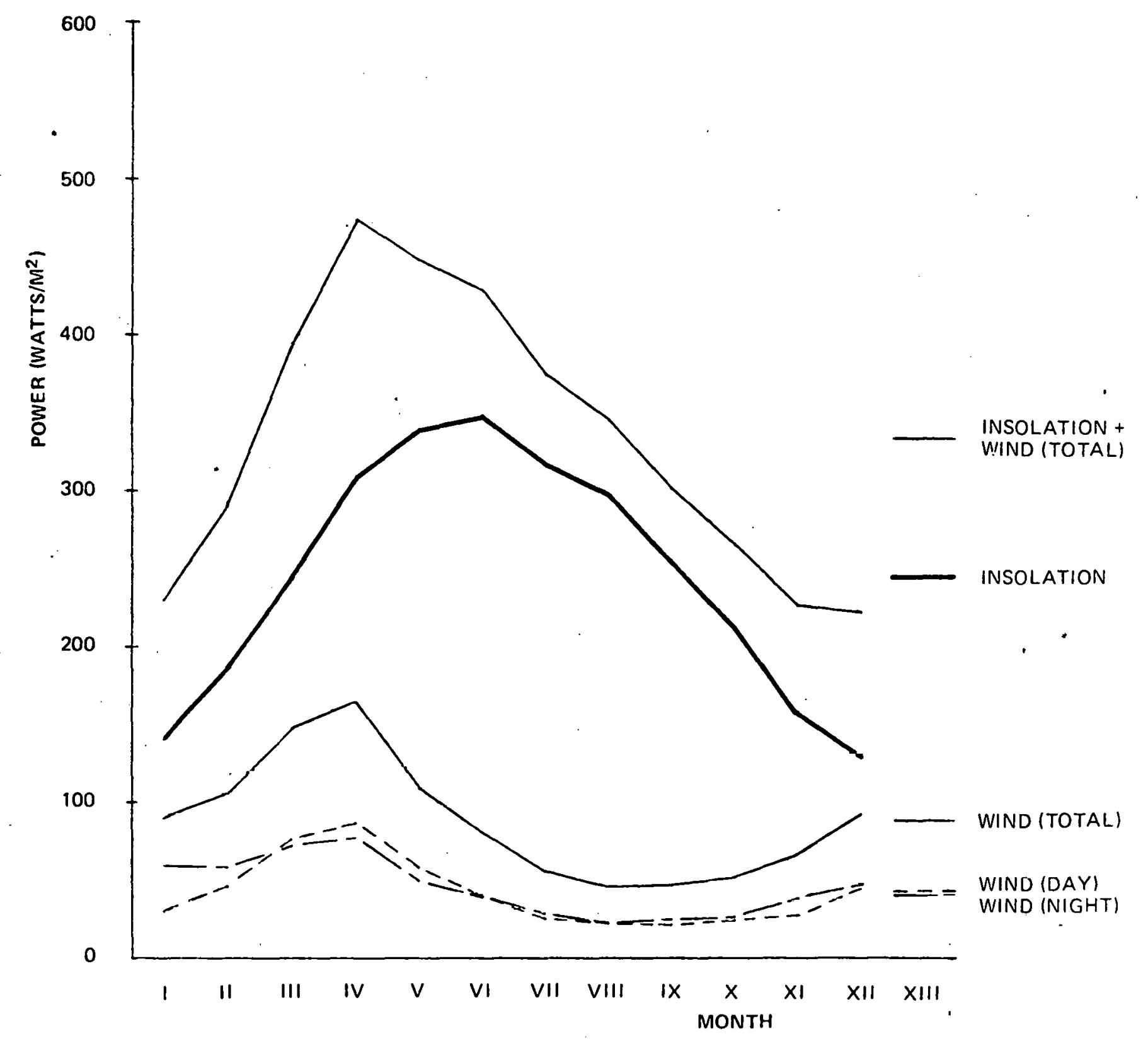

Figure 3-24. DAILY AVERAGE INSOLATION AND WIND POWER, BY MONTH AND ANNUAL ' EL PASO, TX 


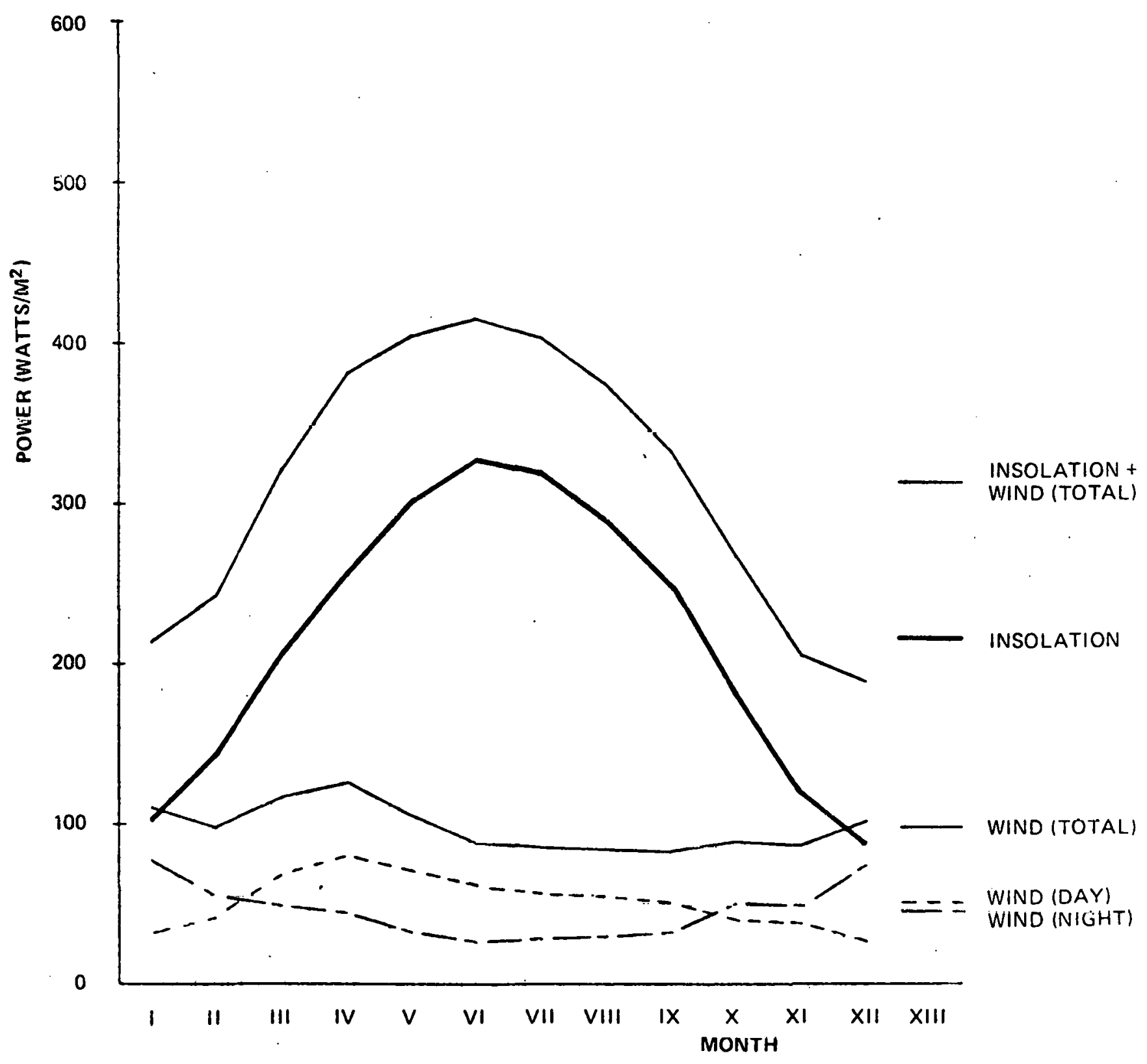

Figure 3-25. DAILY AVERAGE INSOLATION AND WIND POWER, BY MONTH AND ANNUAL $E L Y, N V$ 


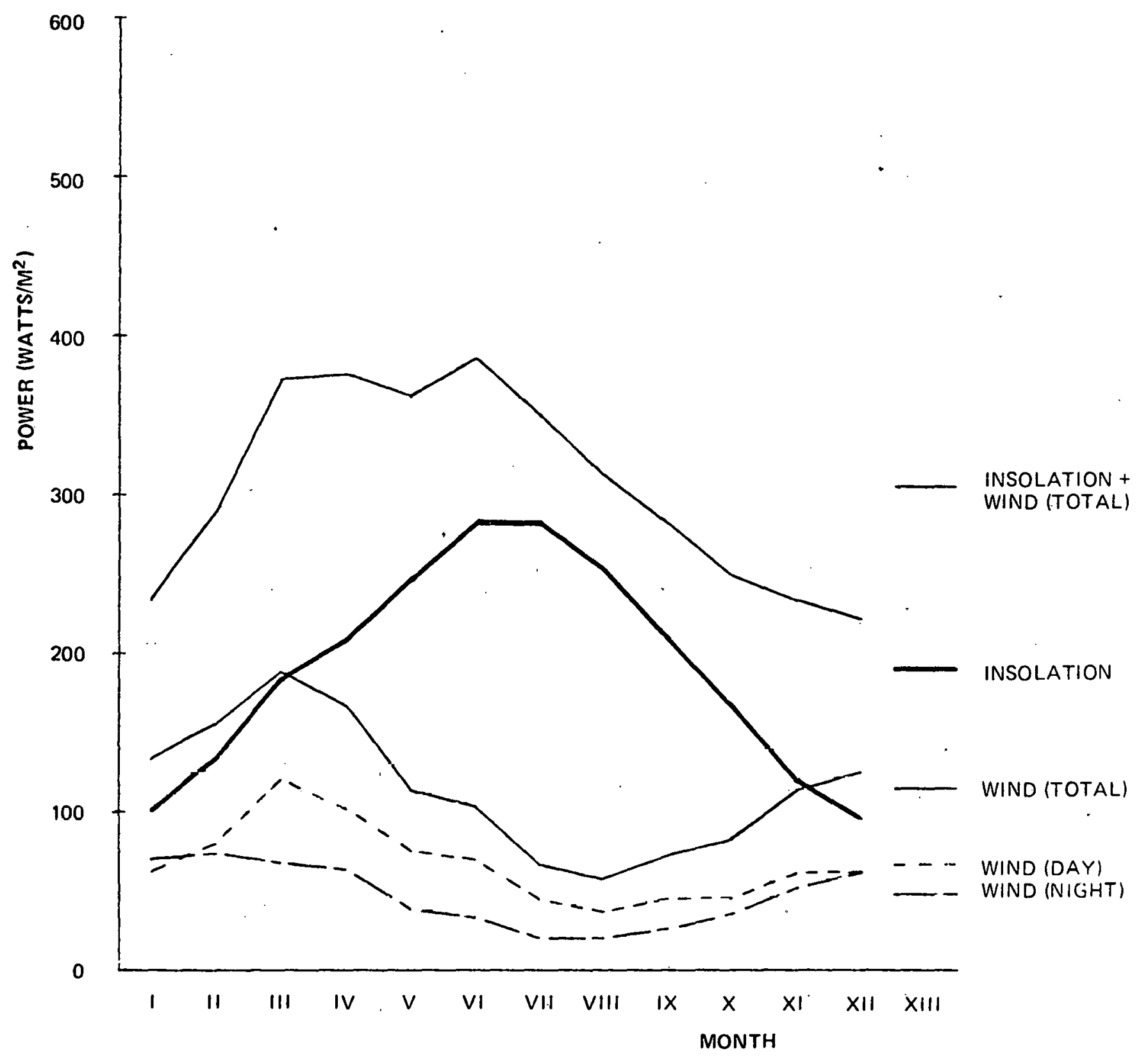

Figure 3-26. DAILY AVERAGE INSSOLATION AND WIND·POWER, BY MONTH AND ANNUAL FORT WORTH, TX 


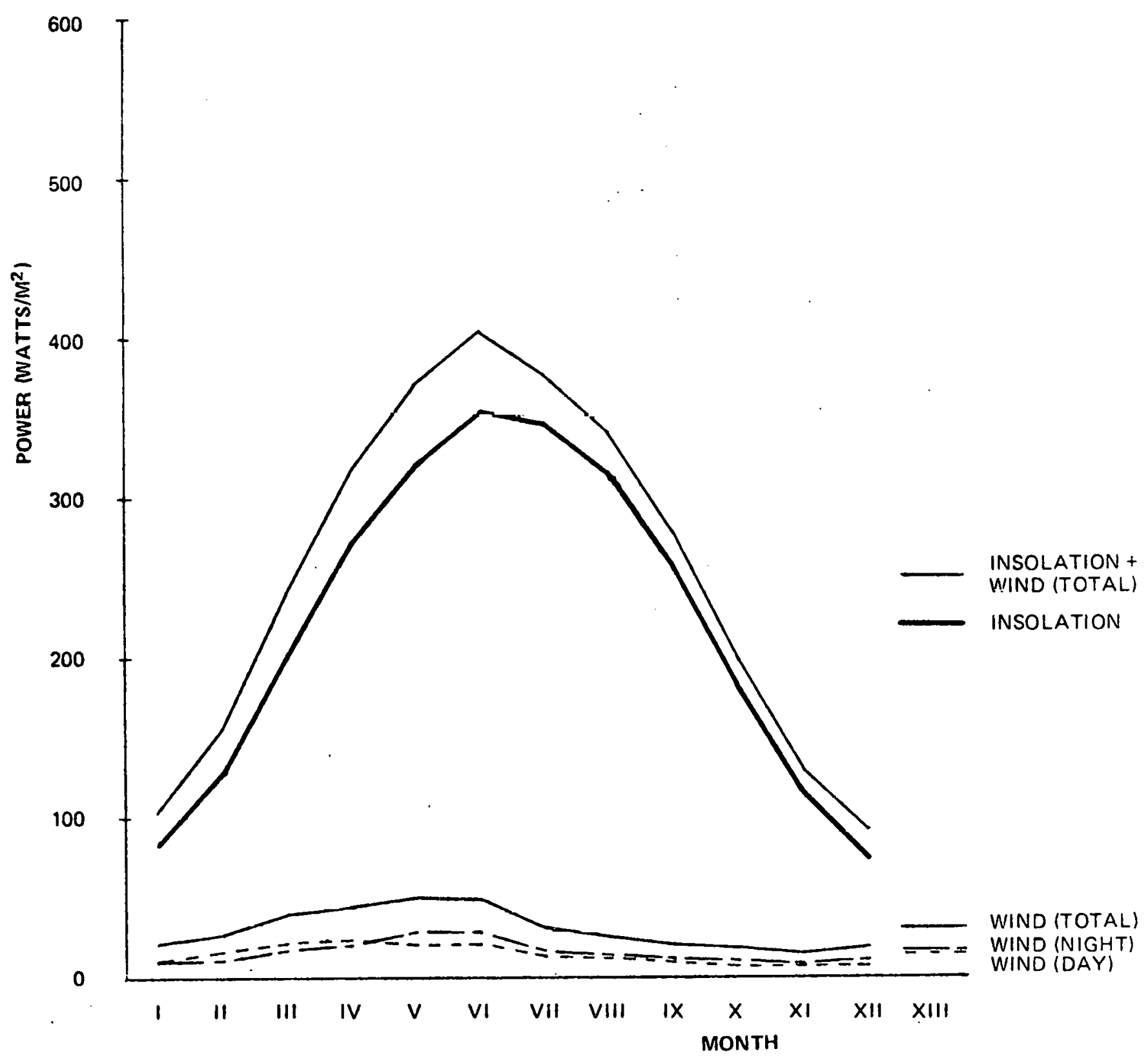

Figure 3-27. DAILY AVERAGE INSOLATION AND WIND POWER, BY MONTH AND ANNUAL FRESNO, CA 


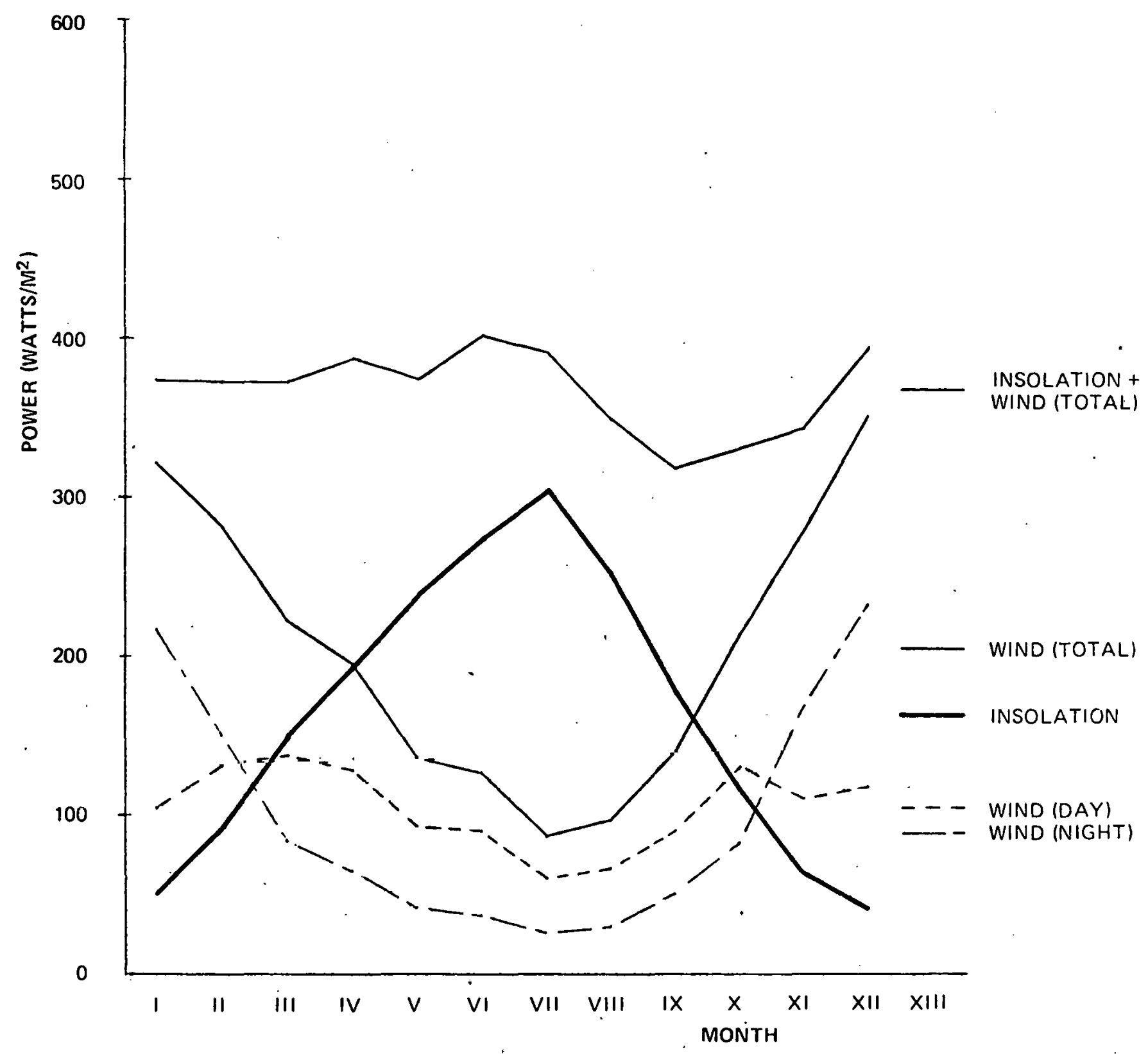

Figure 3-28. DAILY AVERAGE INSOLATION AND WIND POWER, BY MONTH AND ANNUAL GREAT FALLS, MT 


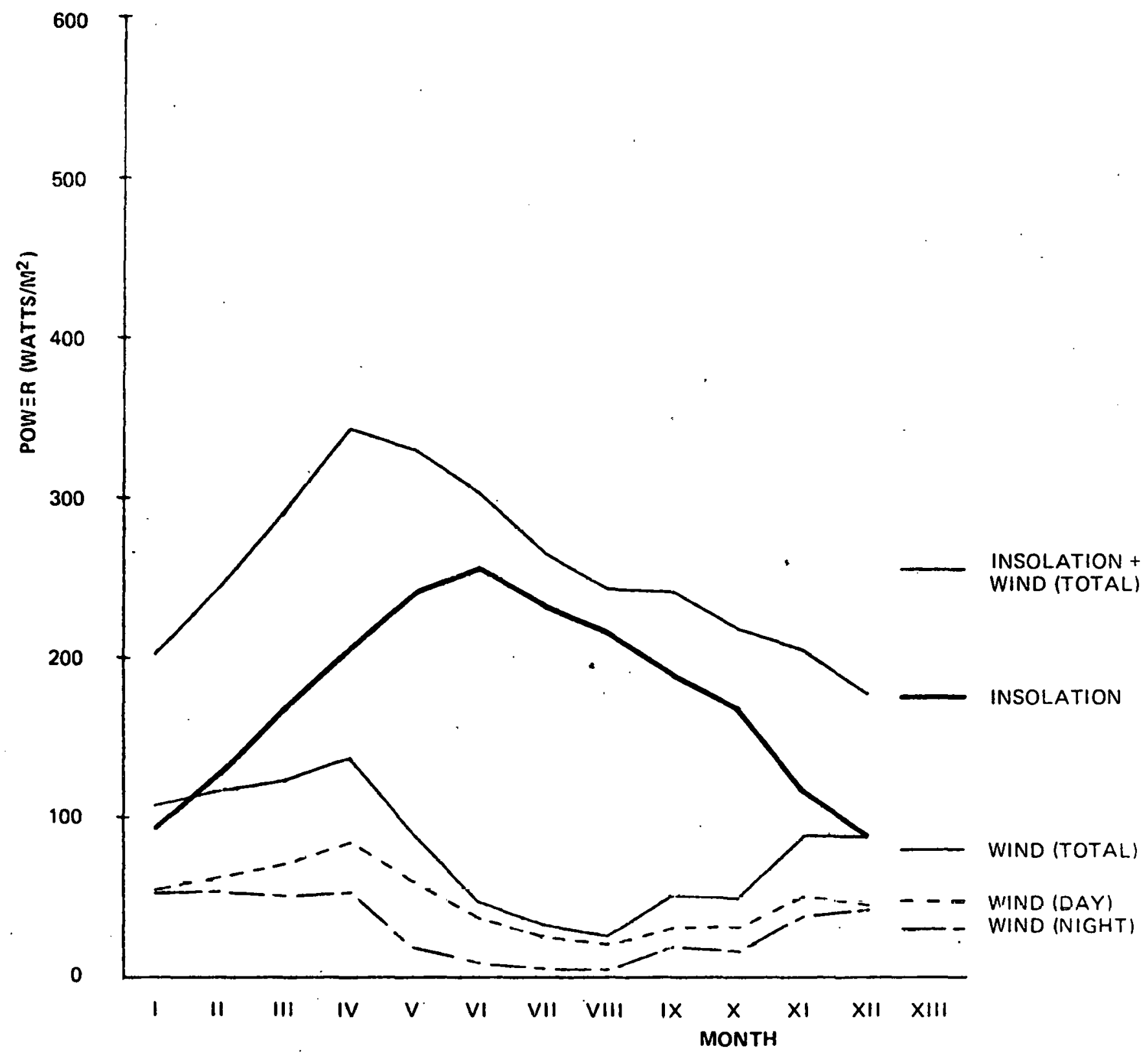

Figure 3-29. DAILY AVERAGE INSOLATION AND WIND POWER, BY MONTH AND ANNUAL LAKE CHARLES, LA. 


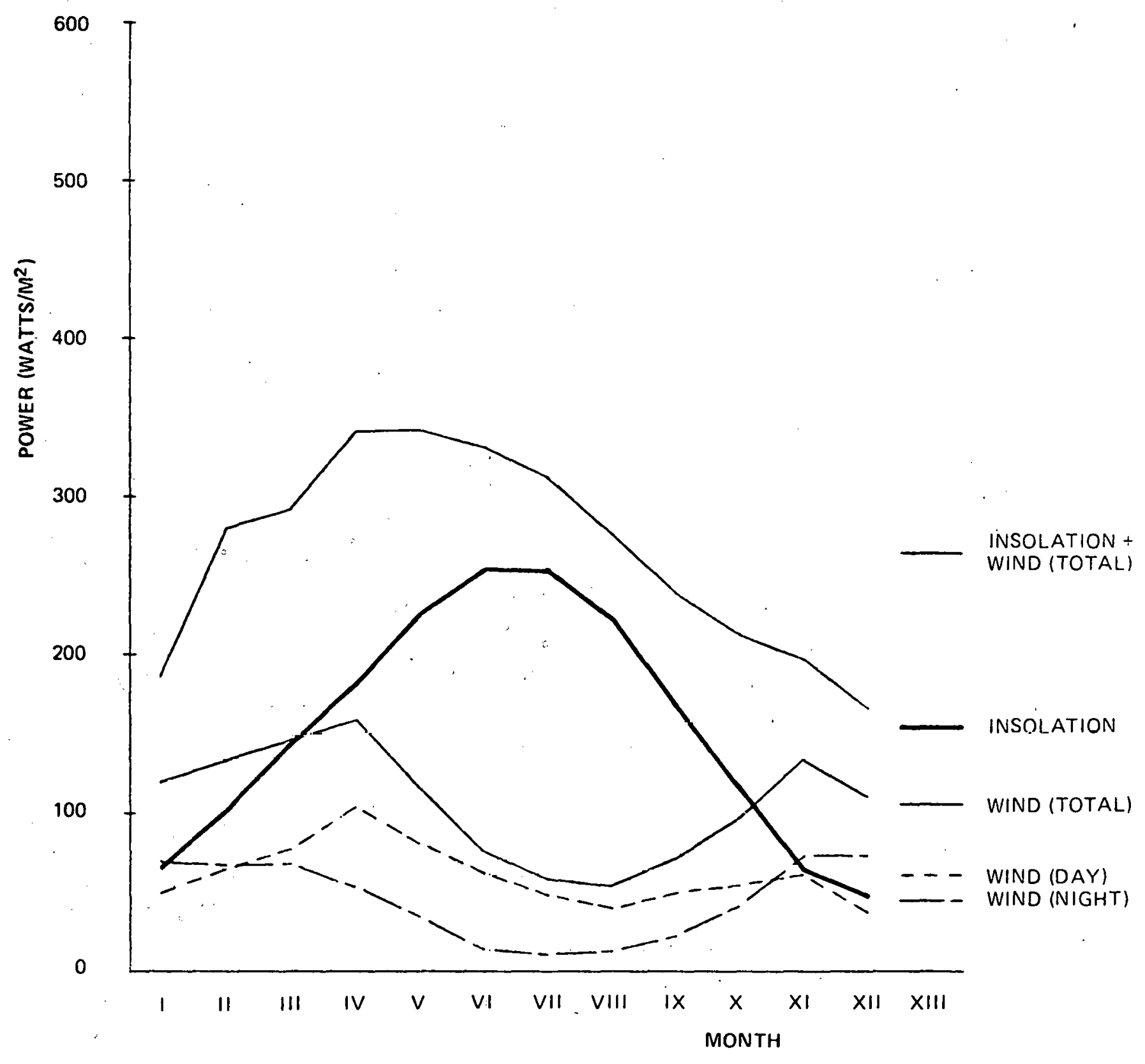

Figure 3-30. DAILY AVERAGE INSOLATION AND WIND POWER, BY MONTH AND ANNUAL MADISON, WI 


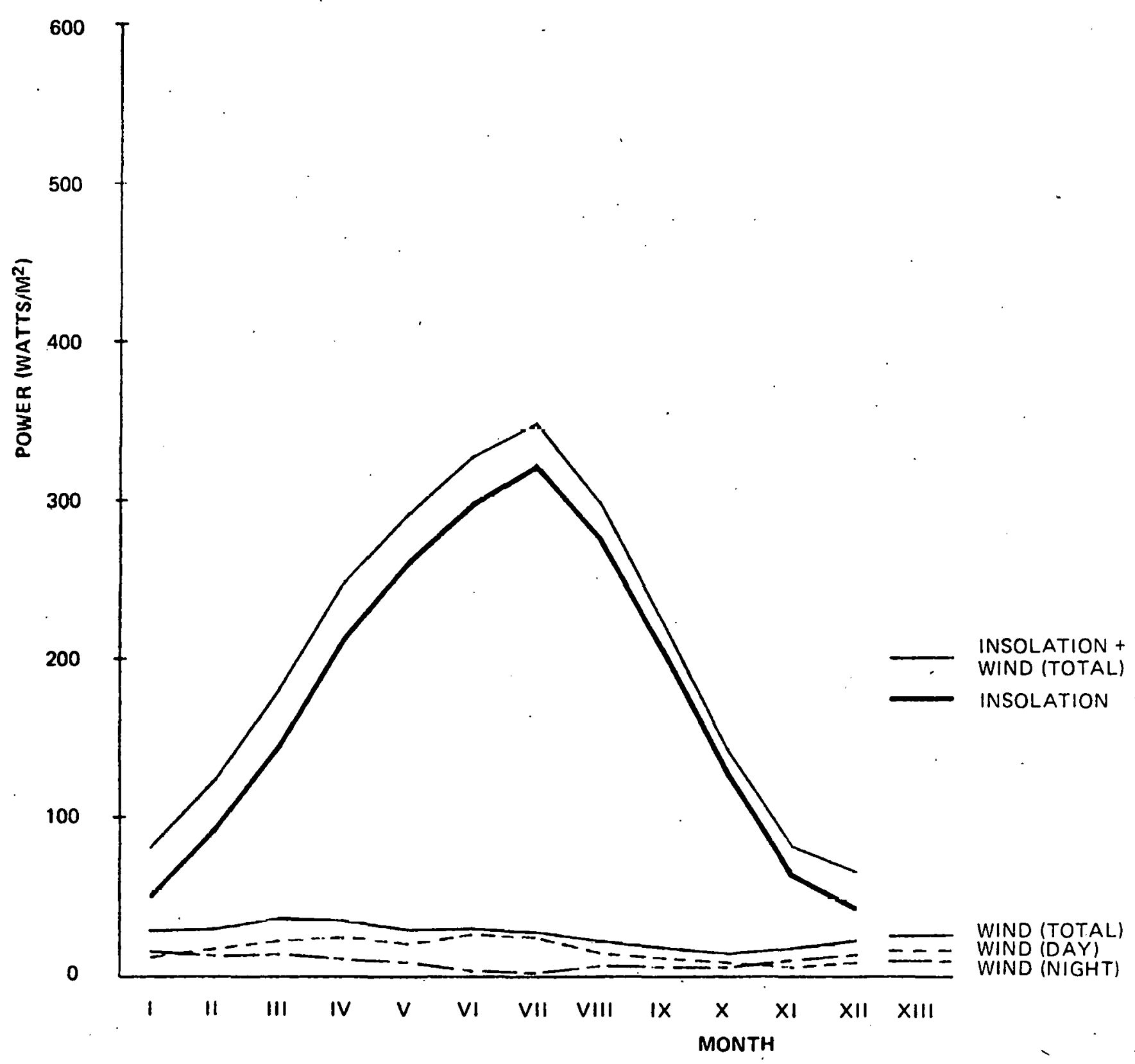

Figure 3-31. DAILY AVERAGE INSOLATION AND WIND POWER, BY MONTH AND ANNUAL MEDFORD, OR 


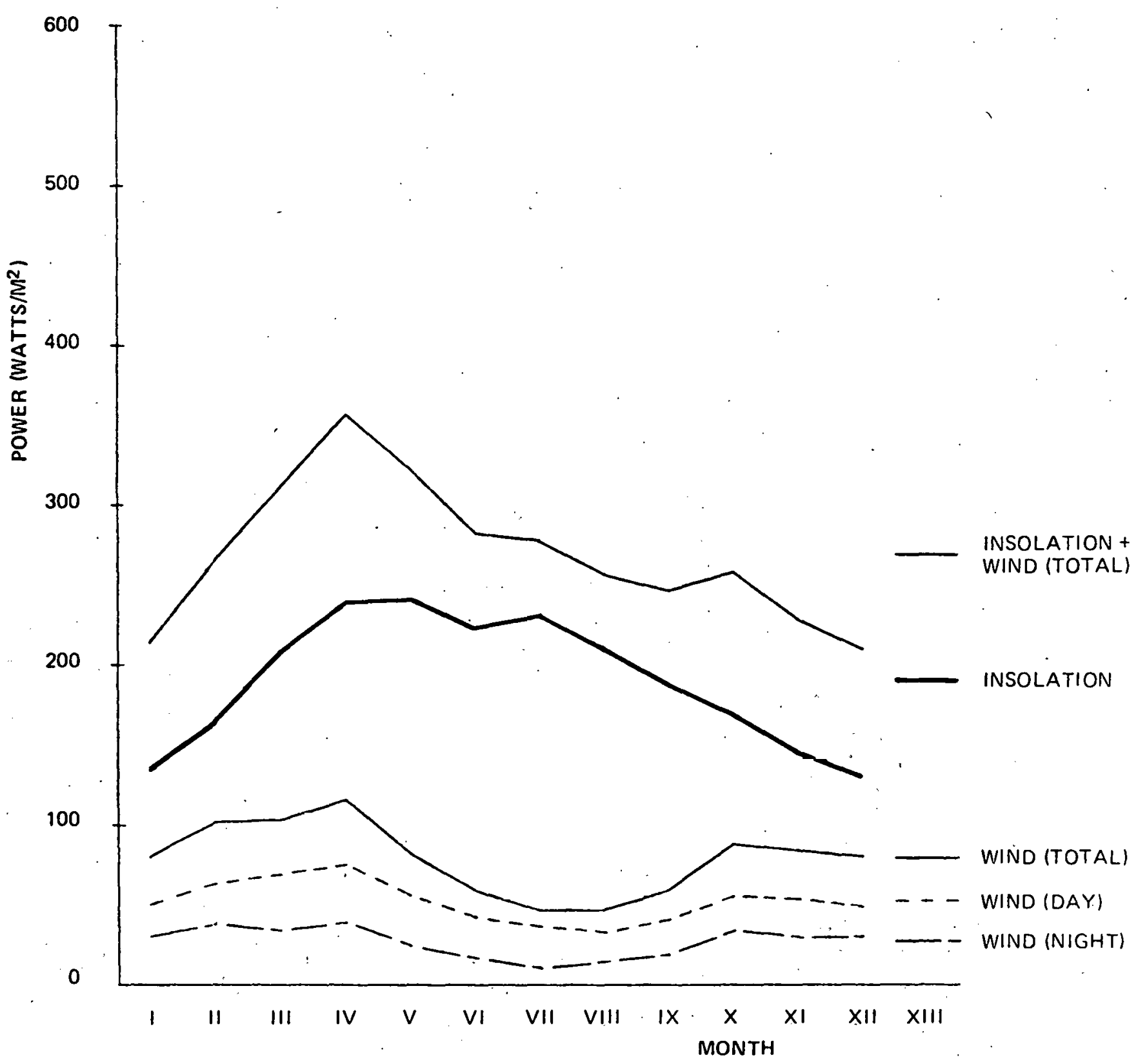

Figure 3-32. DAILY AVERAGE INSOLATION AND WIND POWER, BY MONTH AND ANNUAL MIAMI, FL 


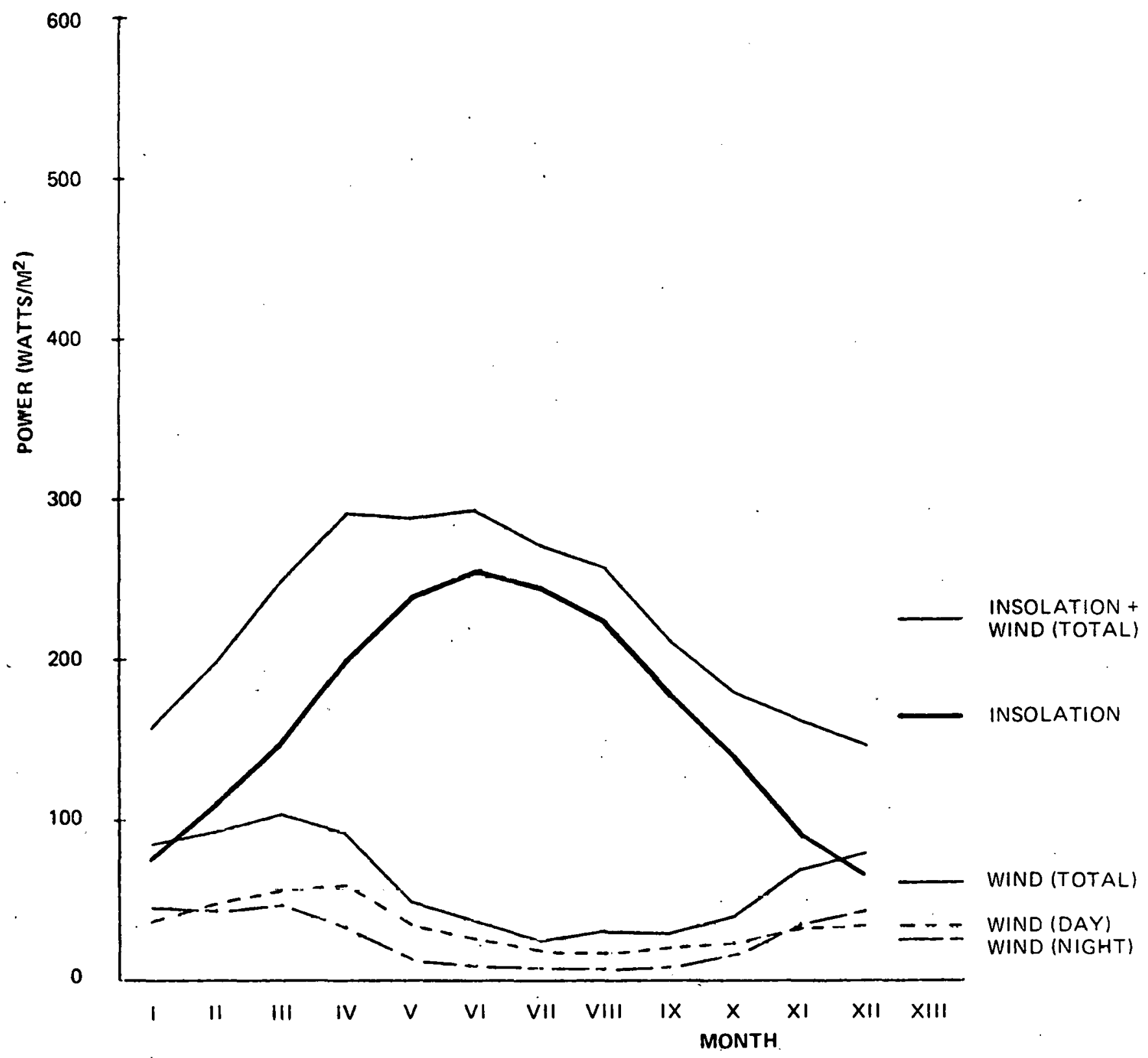

Figure 3-33. DAILY AVERAGE INSOLATION AND WIND POWER, BY MONTH AND ANNUAL NASHVILLE, TN 


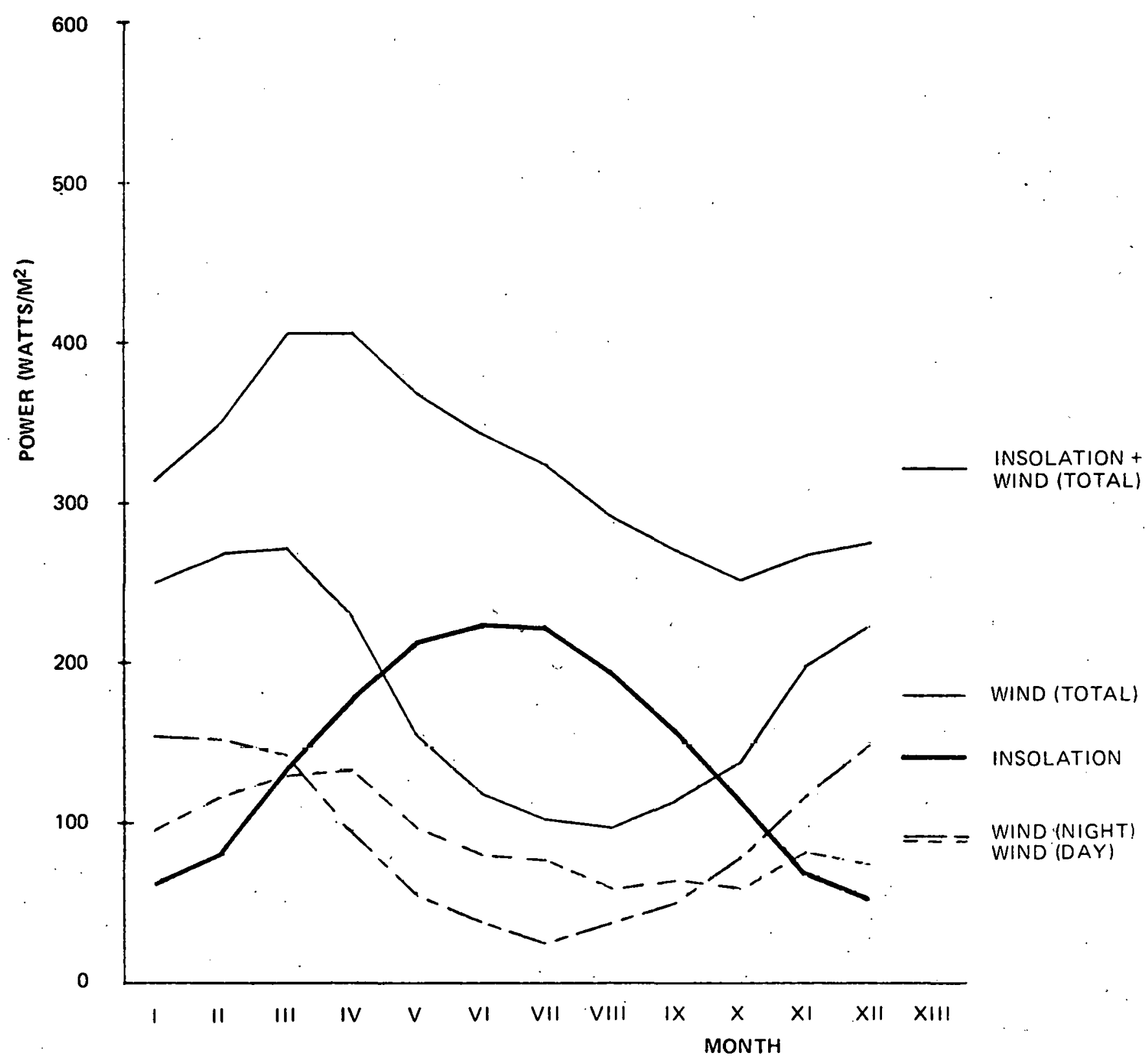

Figure 3-34. DAILY AVERAGE INSOLATION AND WIND POWER, BY MONTH AND ANNUAL -. NEW YORK, NY 


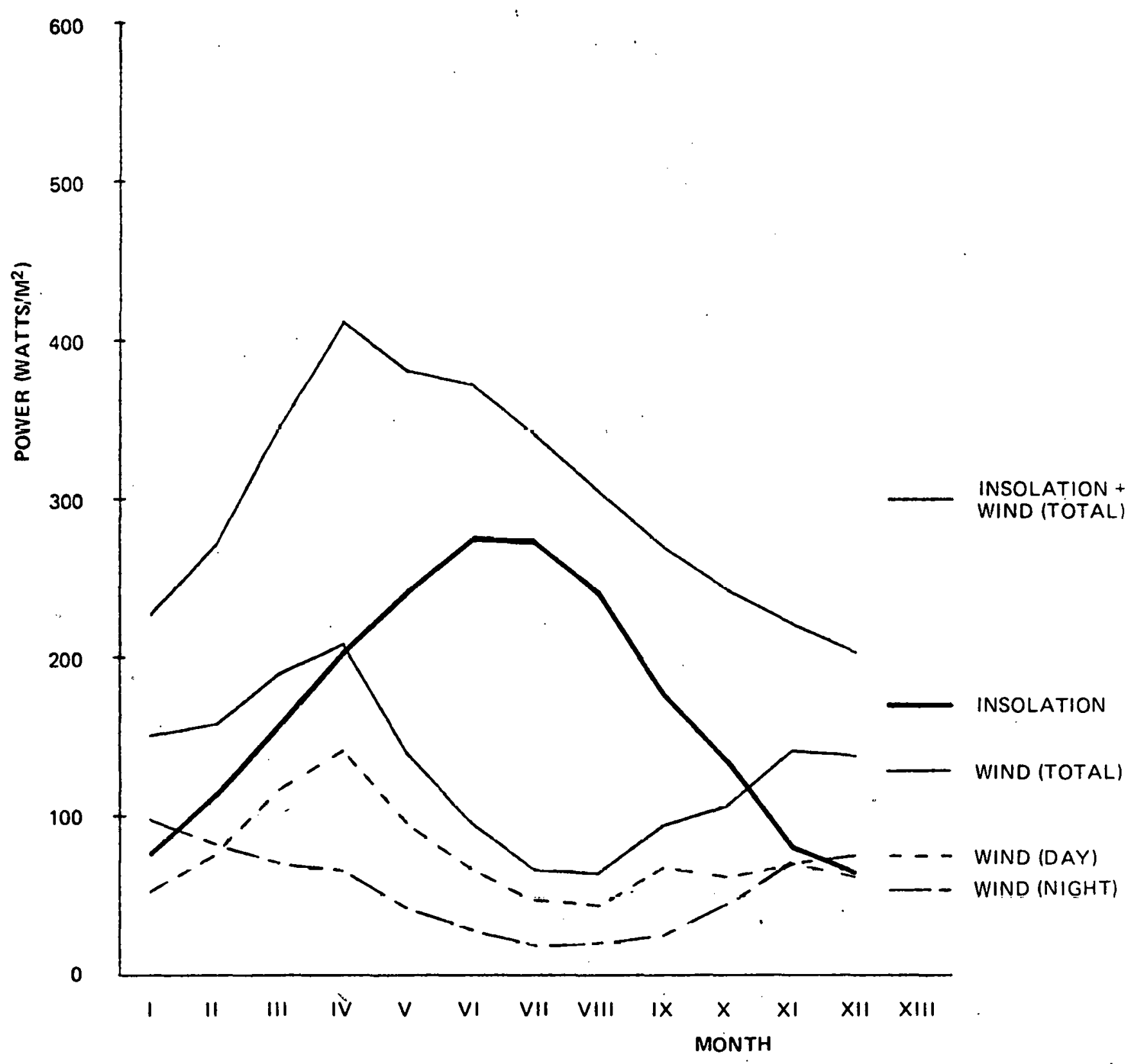

Figure 3-35. DAILY AVERAGE INSOLATION AND WIND POWER, BY MONTH AND ANNUAL NORTH OMAHA, NB 


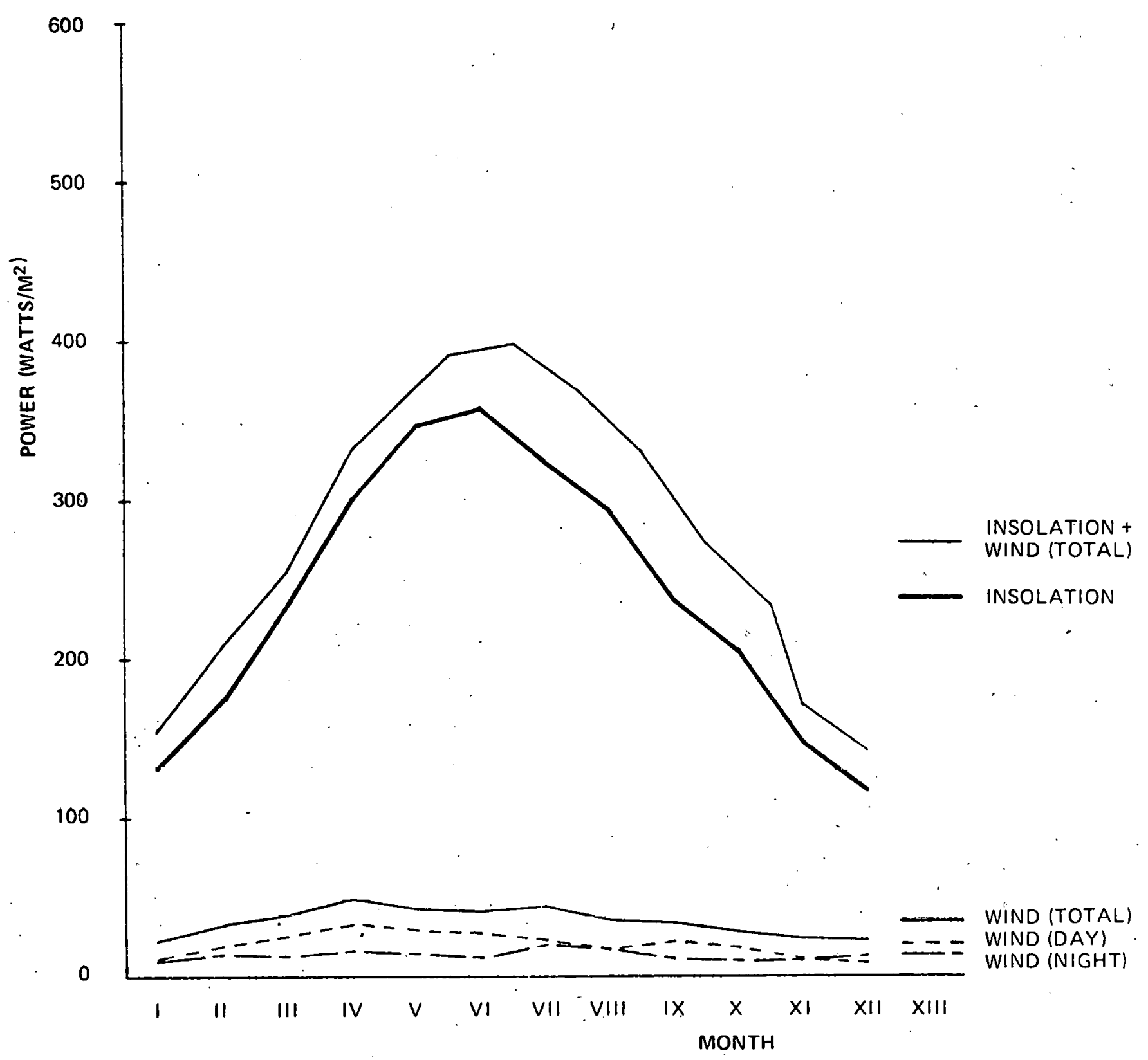

Figure 3-36. DAILY AVERAGE. INSOLATION AND WIND POWER, BY MONTH AND ANNUAL PHOENIX, AZ 


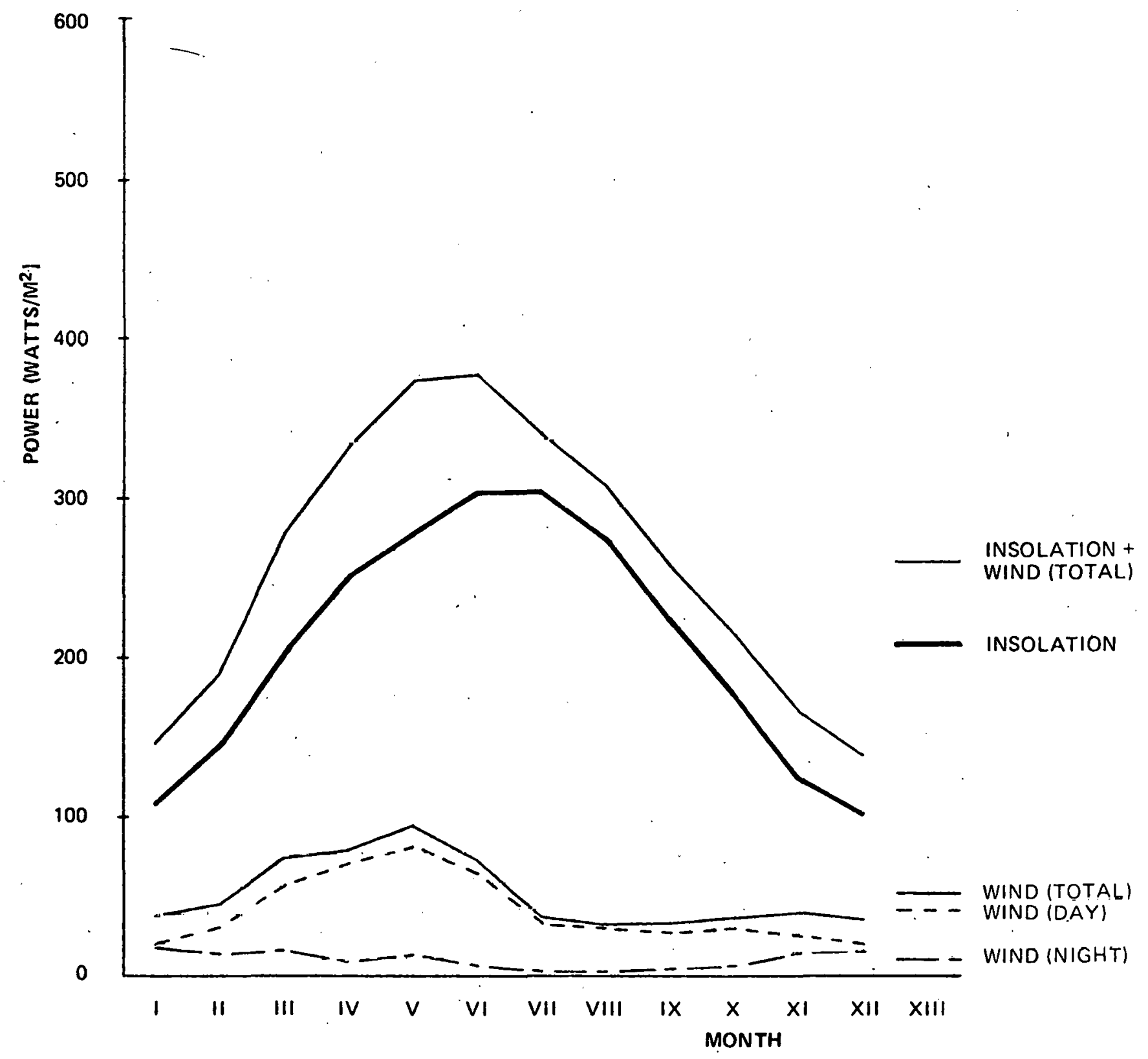

Figure 3-37. DAILY AVERAGE INSOLATION AND WIND POWER, BY MONTH AND ANNUAL SANTA MARIA, CA 


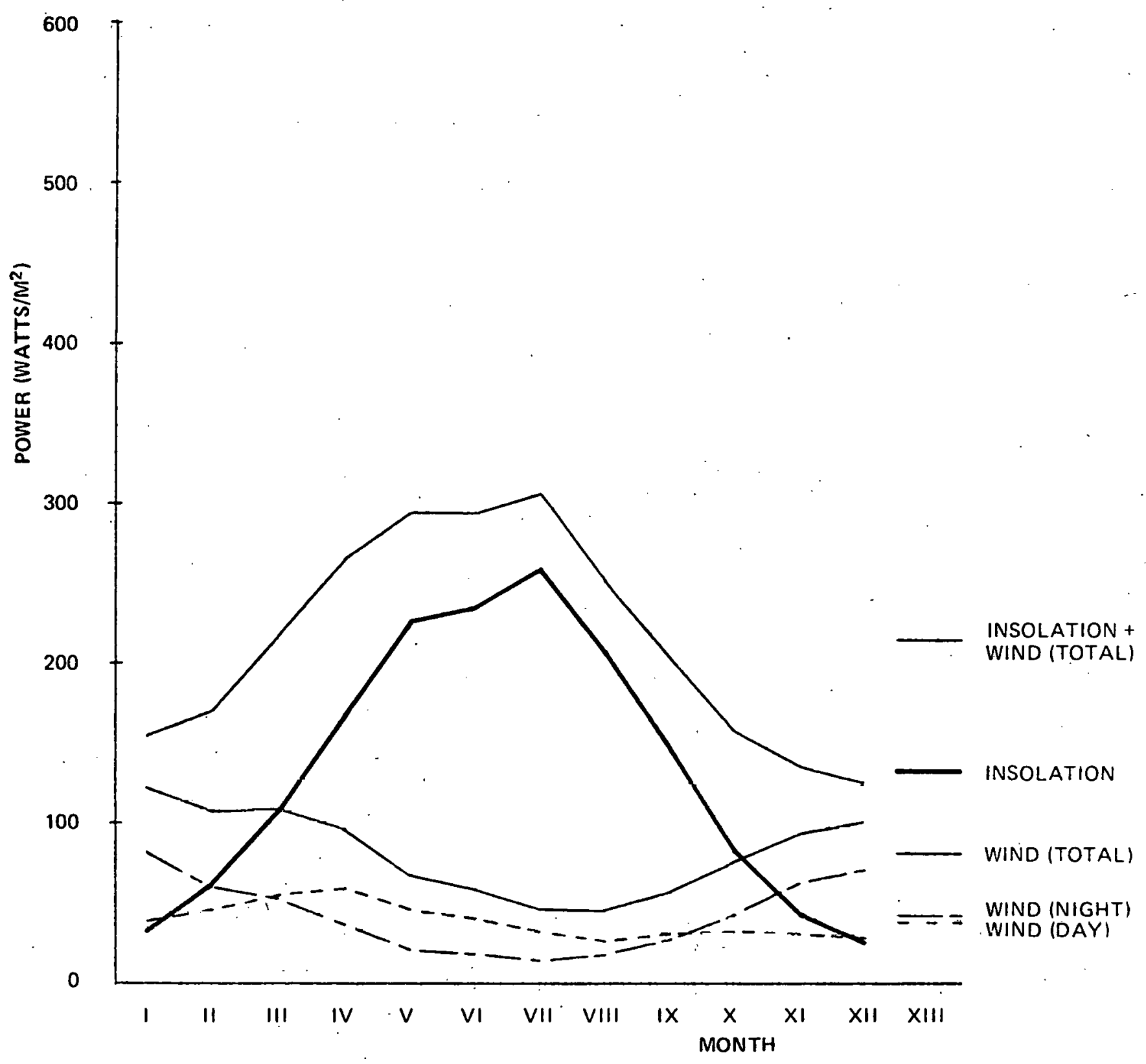

Figure 3-38. DAILY AVERAGE INSOLATION AND WIND POWER, BY MONTH AND ANNUAL SEATTLE-TACOMA, WA 


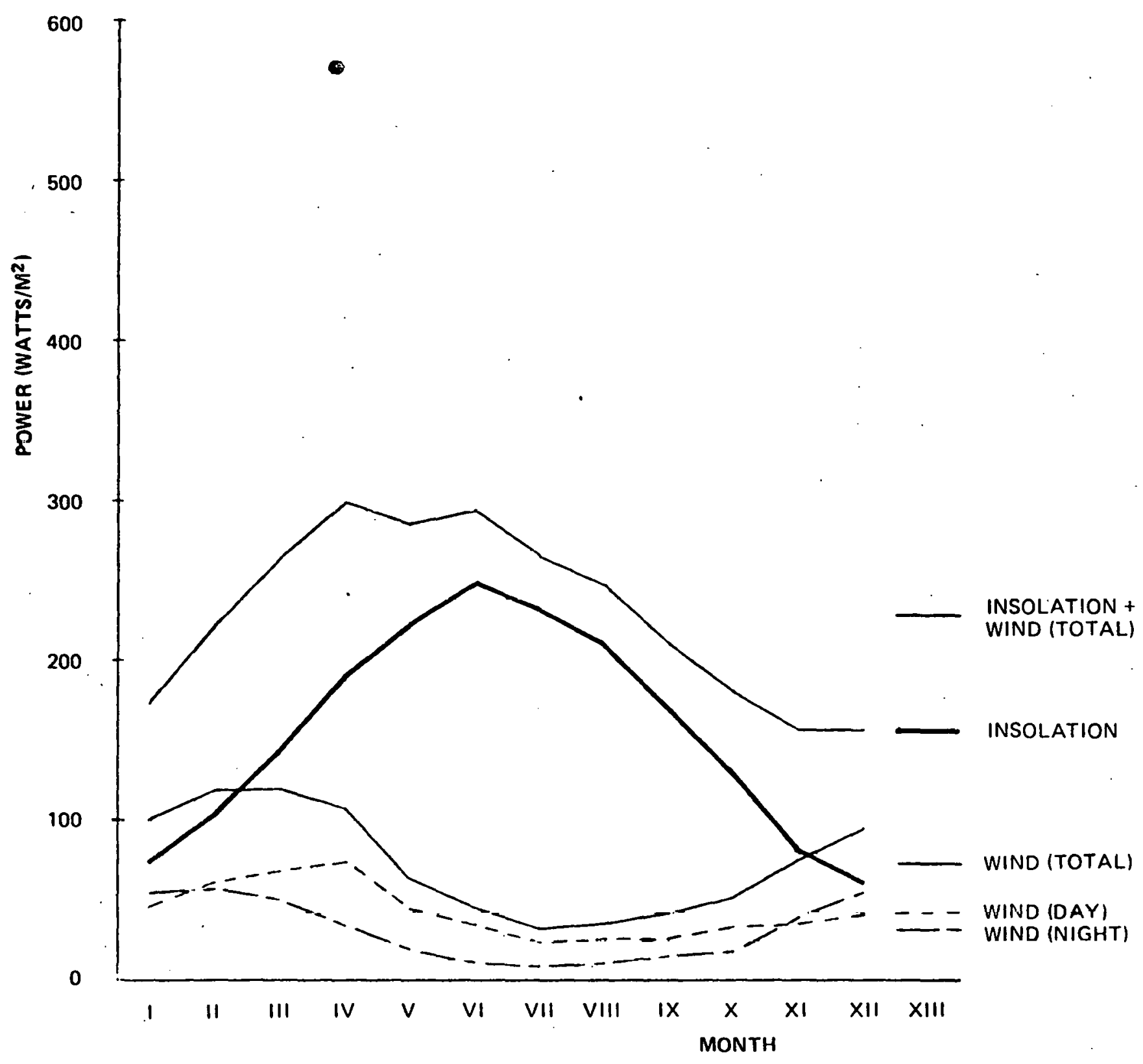

Figure 3-39. DAILY AVERAGE INSOLATION AND WIND POWER, BY MONTH AND ANNUAL WASHINGTON, D.C.-STERLING, VA 
Table 3-1. DAILY AVERAGE INSOLATION AND WIND POWER (Watts/M²)

SEASONAL AND ANNUAL

Albuquerque, NM

$$
\text { WI SP SU FA AN }
$$

Insol. $\quad \begin{array}{lllll}138 & 282 & 332 & 199 & 236\end{array}$

Wind (D) $\begin{array}{lllll}30 & 75 & 36 & 30 & 43\end{array}$

$\begin{array}{llllll}\text { Wind (N) } & 39 & .44 & 38 & 37 & 40\end{array}$

Wind (T) $\quad \begin{array}{lllll}69 & 119 & 74 & 67 & 83\end{array}$

Apalachicola, FL

Inso1. $\quad \begin{array}{lllll}119 & 230 & 235 & 170 & 188\end{array}$

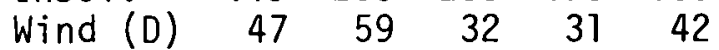

$\begin{array}{llllll}\text { WIND (N) } & 46 & 33 & 11 & 24 & 28\end{array}$

$\begin{array}{llllll}\text { Wind (T) } & 93 & 92 & 43 & 55 & 70\end{array}$

Bismarck, ND

$\begin{array}{llllll}\text { Insol. } & 65 & 190 & 263 & 118 & 159\end{array}$

Wind (D) $\quad \begin{array}{lllll}53 & 130 & 83 & 85 & 88\end{array}$

$\begin{array}{llllll}\text { Wind }(N) & 90 & 53 & 29 & 61 & 59\end{array}$

$\begin{array}{llllll}\text { Wind }(T) & 143 & 183 & 112 & 146 & 147\end{array}$

Boston, MA

$\begin{array}{llllll}\text { Insol. } & 66 & 172 & 218 & 112 & 142\end{array}$

$\begin{array}{llllll}\text { Wind (D) } & 102 & 135 & 74 & 79 & 98\end{array}$

$\begin{array}{llllll}\text { Wind (N) } & 183 & 107 & 42 & 93 & 107\end{array}$

Wind (T) $285 \quad 242 \quad 116 \quad 172 \quad 205$

Brownsville, TX

$\begin{array}{llllll}\text { Insol. } & 123 & 221 & 274 & 181 & 200\end{array}$

$\begin{array}{llllll}\text { Wind (D) } & 91 & 157 & 110 & 73 & 108\end{array}$

$\begin{array}{llllll}\text { Wind }(N) & 63 & 64 & 27 & 32 & 47\end{array}$

$\begin{array}{llllll}\text { Wind }(T) & 154 & 221 & 137 & 105 & 155\end{array}$

Cape Hatteras, NC

$\begin{array}{llllll}\text { Insol } & 97 & 219 & 244 & 150 & 192\end{array}$

$\begin{array}{llllll}\text { Wind (D) } & 73 & 84 & 58 & 65 & 70\end{array}$

$\begin{array}{lllllll}\text { Wind (N) } & 11.6 & 77 & 44 & 76 & 78\end{array}$

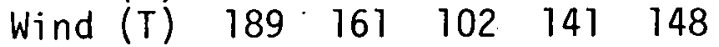

Caribou, ME

$\begin{array}{llllll}\text { Insol. } & 61 & 176 & 217 & 91 & 136\end{array}$

$\begin{array}{llllll}\text { Wind (D) } & 83 & 118 & 77 & 71 & 87\end{array}$

$\begin{array}{llllll}\text { Wind (N) } & 125 & 79 & 22 & 65 & 73\end{array}$

$\begin{array}{llllll}\text { Wind }(T) & 208 & 197 & 99 & 136 & 160\end{array}$
Charleston, SC

WI SP SU FA AN

$\begin{array}{llllll}\text { Insol. } \quad 104 & 213 & 228 & 151 & 174\end{array}$

Wind (D) $53^{\circ} 68.41 \quad 38 \quad 50$

$\begin{array}{llllll}\text { Wind }(N) & 44 & 33 & 11 & 24 & 28\end{array}$

$\begin{array}{llllll}\text { Wind }(T) & 97 & 101 & 52 & 62 & 78\end{array}$

Columbia, MO

$\begin{array}{llllll}\text { Insol. } & 85 & 198 & 264 & 139 & 172^{\circ}\end{array}$

Wind (D) $\begin{array}{lllll}58 & 76 & 32 & 41 & 52\end{array}$

$\begin{array}{llllll}\text { Wind (N) } & 64 & 50 & 13 & 38 & 42\end{array}$

$\begin{array}{llllll}\text { Wind (T) } & 122 & 126 & 45 & 79 & 94\end{array}$

Dodge City, KS

$\begin{array}{llllll}\text { Insol. } & 110 & 232 & 289 & 165 & 199\end{array}$

$\begin{array}{llllll}\text { Wind (D) } & 89 & 165 & 113 & 105 & 118\end{array}$

$\begin{array}{llllll}\text { Wind (N) } & 121 & 110 & 60 & 88 & 95\end{array}$

$\begin{array}{llllll}\text { Wind }(T) & 210 & 275 & 173 & 193 & 213\end{array}$

El Paso, TX

Insol. $\quad \begin{array}{lllll}152 & 297 & 290 & 208 & 245\end{array}$

Wind (D) $\begin{array}{lllll}40 & 74 & 30 & 25 & 43\end{array}$

Wind (N) $\begin{array}{lllll}55 & 66 & 31 & 30 & 42\end{array}$

$\begin{array}{llllll}\text { Wind }(T) & 95 & 140 & 61 & 55 & 85\end{array}$

Ely; NV

$\begin{array}{llllll}\text { Insol. } \quad 112 & 254 & 311 & 182 & 215\end{array}$

Wind (U) $\begin{array}{lllll}34 & 73 & 57 & 42 & 52\end{array}$

$\begin{array}{llllll}\text { Wind (N) } & 70 & 43 & 28 & 44 & 46\end{array}$

$\begin{array}{llllll}\text { Wind (T) } & 1.04 & 116 & 85 & 86 & 98\end{array}$

Fort Worth, TX

Insol. $111 \quad 213 \quad 272: 165 \quad 190$

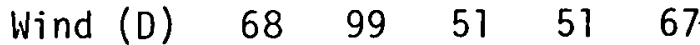

Wind (N) $\quad 69 \quad 57.25 \quad 38 \quad 48$

$\begin{array}{llllll}\text { Wind }(T) & 137 & 156 & 76 & 89 & 115\end{array}$

Fresno, CA

$\begin{array}{llllll}\text { Insol. } & 95 & 265 & 339 & 183 & 221\end{array}$

Wind (D) $\quad \begin{array}{lllll}11 & 23 & 15 & 8 & 14\end{array}$

Wind (N) $\begin{array}{lllll}11 & 22 & 20 & 10 & 16\end{array}$ 
Table 3-1. DAILY AVERAGE INSOLATION AND WIND POWER (Watts/M²)
SEASONAL AND ANNUAL (Concluded)

Great Falls, MT

$\begin{array}{lrrrrr} & \text { WI } & \text { SP } & \text { SU } & \text { FA } & \text { AN } \\ \text { Insol. } & 62 & 194 & 276 & 119 & 163 \\ \text { Wind (D) } & 118 & 120 & 72 & 110 & 105 \\ \text { Wind (N) } & 200 & 63 & 31 & 101 & 89 \\ \text { Wind (T) } & 318 & 183 & 103 & 211 & 194\end{array}$

Lake Charles, LA

Insol. 103. $205 \quad 235 \quad 158 \quad 175$

$\begin{array}{llllll}\text { Wind (D) } & 55 & 72 & 28 & 37 & 48\end{array}$

$\begin{array}{llllll}\text { Wind (N) } & 50 & 44 & 7 & 25 & 32\end{array}$

$\begin{array}{llllll}\text { Wind }(T) & 105 & 116 & 35 & 62 & 80\end{array}$

Madison, WI

$\begin{array}{llllll}\text { Insol. } & 72 & 184 & 243 & 115 & 154\end{array}$

Wind (D) $\quad 51 \quad 88 \quad 50 \quad 55 \quad 61$

Wind (N) $\begin{array}{llllll}70 & 53 & 13 & 45 & 45\end{array}$

$\begin{array}{llllll}\text { Wind }(T) & 121 & 147 & 63 & 100 & 106\end{array}$

Medford, OR

Insol. $\quad \begin{array}{lllll}63 & 207 & 298 & 131 & 175\end{array}$

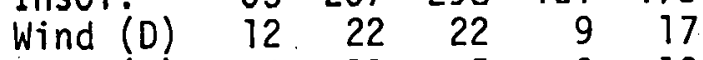

Wind (N) $\begin{array}{llllll}14 & 11 & 5 & 8 & 10\end{array}$

Wind $(T) \quad \begin{array}{lllll}26 & 33 & 27 & 17 & 27\end{array}$

Miami, FL

Insol. $\quad \begin{array}{llllll}143 & 229 & 221 & 168 & 190\end{array}$

Wind (D) $\begin{array}{rrrrr}54 & 66 & 37 & 49 & 52\end{array}$

Wind (N) $\begin{array}{lllll}33 & 33 & 14 & 27 & 27\end{array}$

$\begin{array}{llllll}\text { Wind }(T) & 87 & 99 & 51 & 76 & 79\end{array}$

Nashville, TN

$\begin{array}{llllll}\text { Insol: } & 82 & 193 & 242 & 138 & 164\end{array}$

Wind (D) $\begin{array}{lllll}39 & 50 & 21 & 26 & 34\end{array}$

$\begin{array}{llllll}\text { Wind }(N) & 45 & 32 & 8 & 20 & 26\end{array}$

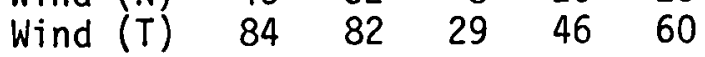

New York, NY

$\begin{array}{lrrrrr} & \text { WI } & \text { SP } & \text { SU } & \text { FA } & \text { AN } \\ \text { Insol. } & 65 & 175 & 216 & 113 & 147 \\ \text { Wind (D) } & 95 & 119 & 72 & 68 & 89 \\ \text { Wind (N) } & 152 & 98 & 33 & 82 & 92 \\ \text { Wind (T) } & 247 & 217 & 105 & 150 & 181\end{array}$

North Omaha; NB

$\begin{array}{lrrrrr}\text { Insol. } & 85 & 201 & 263 & 131 & 170 \\ \text { Wind (D) } & 63 & 119 & 53 & 67 & 76 \\ \text { Wind (N) } & 86 & 60 & 23 & 46 & 54 \\ \text { Wind (T) } & 149 & 179 & 76 & 113 & 130\end{array}$

Phoenix, AZ

$\begin{array}{llllll}\text { Insol. } & 141 & 294 & 325 & 197 & 239\end{array}$

Wind (D) $\begin{array}{lllll}13 & 30 & 23 & 18 & 21\end{array}$

$\begin{array}{llllll}\text { Wind (N) } & 13 & 14 & 17 & 11 & 14\end{array}$

$\begin{array}{llllll}\text { Wind }(T) & 26 & 44 & 40 & 29 & 35\end{array}$

Santa Maria, CA

Insol. $\quad \begin{array}{llllll}118 & 244 & 294 & 175 & 208\end{array}$

$\begin{array}{llllll}\text { Wind (D) } & 23 & 70 & 43 & 28 & 41\end{array}$

Wind (N) $\begin{array}{llllll}16 & 13 & 4 & 9 & 11\end{array}$

$\begin{array}{llllll}\text { Wind }(T) & 39 & 83 & 47 & 37 & 52\end{array}$

Seattle-Tacoma, WA :

Insol. $\quad \begin{array}{lllll}40 & 167 & 233 & 90 & 133\end{array}$

Wind (D) $\begin{array}{lllll}38 & 53 & 33 & 31 & 39\end{array}$

$\begin{array}{llllll}\text { Wind (N) } & 72 & 37 & 17 & 44 & 43\end{array}$

$\begin{array}{llllll}\text { Wind }(T) & 110 & 90 & 50 & 75 & 82\end{array}$

Washington, DC - Sterling, VA

Insol. $\quad \begin{array}{lllll}79 & 185 & 231 & 127 & 156\end{array}$

Wind (D) $\begin{array}{lllll}49 & 62 & 28 & 31 & 43\end{array}$

Wind (N) $\begin{array}{rrrrr}55 & 35 & 10 & 24 & 37\end{array}$ 
Section IV

REFERENCES

1. Baumeister, T., Mechanical Engineers' Handbook, Mc-Graw-Hill Book Co., Sixth Edition, 1958.

2. Carter, E. A., "Basic Relationships to Determine Wind Power and Solar Radiation Available from the Atmosphere", Proceedings of the Second Southeastern Conference on Applications of Solar Energy, Baton Rouge, Louisiana, ERDA CONF-760423, April 19-22, 1976, pp. 381-389.

3. Carter, E. A. and Graves, M. E., "A Procedure and Computer Program to Interrogate Weather Records and Infer the Probability that Combinations of Weather Criteria will be Satisfied", Northrop Services, Inc., Huntsville, Alabama, Technical Report, TR-230-1369, November 1974.

4. Changery, M. J., "(Initial) Wind Energy Data Assessment Study", Data Assessment Conference, Asheville, North Carolina, NSF-RA-N-75-020; July 1974 .

5. Coty, U. A., "Wind Energy Mission Anälyss1s - Flual Reyort", Lockhoed Calif. Co.-Burbank, ERDA SAN/1075-1/1, September 1976.

6. Graves, M. E., "An Evaluation of Environmental Constraints for Space Shuttle Launch and Landing Operations," Northrop Services, Inc., Technical Report, TR-230-1488, June 1975.

7. Gringorten, I. I., "A Stochastic Model of the Frequency and Duration of Weather Events", Journal of Applied Meteorology, 5, 1966, pp. 606-624.

8. Lund, I. A. and Grantham, D. D., "Estimating Hourly Persistence and Recurrence Probabilities of Persistence", Fourth Conference on Probability and Statistics in Atmospheric Sciences, Tallahassee, Florida, November 1975.

9. Reed, J. W., "Wind Power Climatology of the United States", Sandia Laboratories, Albuquerque, New Mexico, SAND74-0348, June 1975.

10. SOLMET, Volume I-User's Manual, "Hourly Solar Radiation-Surface Meteorological Observations", National Climatic Center (NOAA), TD-9724, December 1977. 